2014-06-01

\title{
Response of wave-dominated and mixed-energy barriers to storms
}

\author{
Masselink, Gerd
}

http://hdl.handle.net/10026.1/3092

10.1016/j.margeo.2013.11.004

MARINE GEOLOGY

Elsevier BV

All content in PEARL is protected by copyright law. Author manuscripts are made available in accordance with publisher policies. Please cite only the published version using the details provided on the item record or document. In the absence of an open licence (e.g. Creative Commons), permissions for further reuse of content should be sought from the publisher or author. 


\section{RESPONSE OF WAVE-DOMINATED AND MIXED-ENERGY BARRIERS TO STORMS}

Gerd Masselink $^{1} \&$ Sytze van Heteren ${ }^{2}$

${ }^{I}$ School of Marine Science and Engineering, Plymouth University, Plymouth, UK

${ }^{2}$ Geological Survey of the Netherlands, Utrecht, The Netherlands

Marine Geology, 352, 321-347, doi: 10.1016/j.margeo.2013.11.004

http://www.sciencedirect.com/science/article/pii/S0025322713002442

NOTICE: this is the author's version of a work that was accepted for publication in Marine Geology. Changes resulting from the publishing process, such as peer review, editing, corrections, structural formatting, and other quality control mechanisms may not be reflected in this document. Changes may have been made to this work since it was submitted for publication. A definitive version was subsequently published in Marine Geology, [VOL 352, (15th Nov 2013 )] DOI 10.1016/j.margeo.2013.11.004

Response of wave-dominated and mixed-energy barriers to storms (11,700 words; 22 figures; 1 table)

Abstract (500 words)

1. Introduction (1200; 2 figures)

2. Long-term influences: sea-level change and storminess $(\mathbf{1 0 0 0} ; \mathbf{1}$ figure $)$

3. Factors influencing the impact of individual storms (1200)

4. Hydrodynamic processes during storms (2100; 6 figures, 1 table)

4.1 Weather and storm surge (300; 1 figure)

4.2 Surf zone waves and currents (900; 4 figures, 1 table)

4.3 Sediment fluxes and budgets (900; 1 figure)

5. Barrier response to storm-generated hydrodynamic processes (3600; 4 figures)

5.1 Storm-Impact Scale model and the role of freeboard (700; 1 figure)

5.2 Swash regime (900; 2 figures)

5.3 Collision regime (600; 1 figure)

5.4 Overwash regime $(600)$

5.5 Inundation regime $(600)$

5.6 Long-term response (200)

6. Spatial and temporal patterns $(1600 ; 3$ figures $)$

7. Thresholds and feedback mechanisms (1000; 1 figure)

8. Synthesis and conclusion (1200, $\mathbf{5}$ figures)

References (200 references; 5400 words)

\section{Graphic summary}

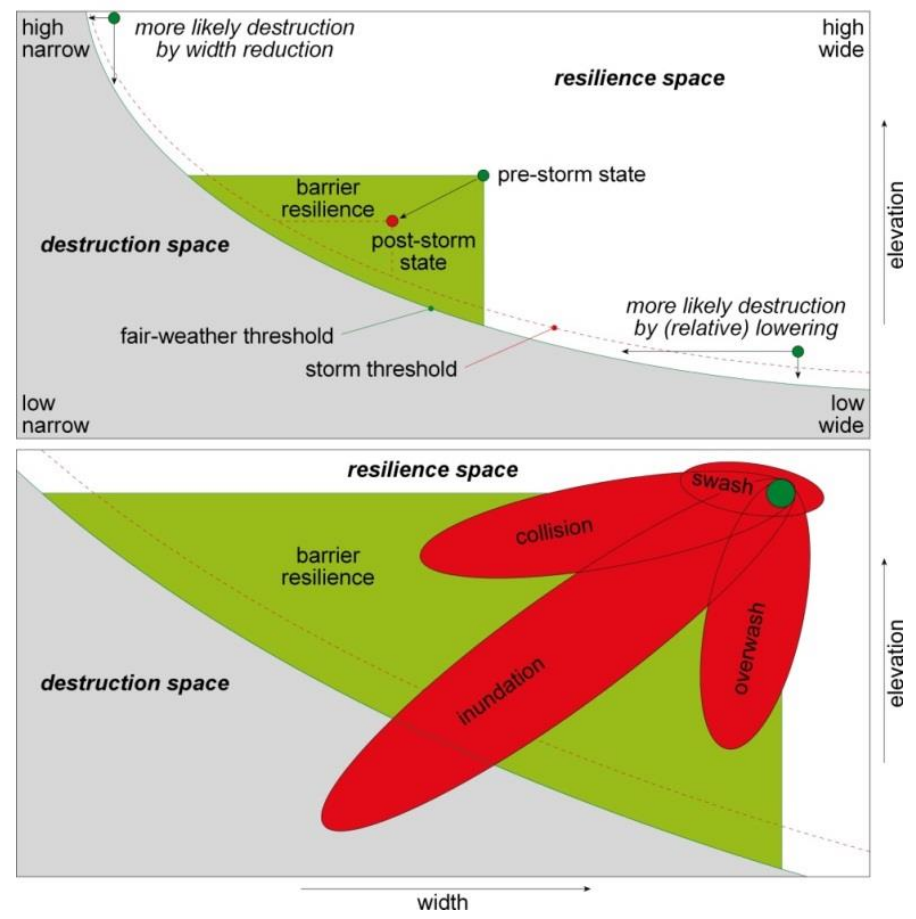


- Wave-dominated and mixed-energy barriers are extremely dynamic landforms, responding to warm-core tropical and cold-core extratropical cyclones.

- Barrier storm response is primarily governed by maximum storm runup and barrier morphology, as conceptualised in Abby Sallenger's Storm Impact Scale model, which defines four storm-impact regimes: swash regime, collision regime overwash regime and inundation regime.

- Site-specific factors play a key role in moderating the morphological response and include storm characteristics (type, duration and track), longshore sediment supply, upwelling-downwelling currents, coastal setting and inner-shelf topography.

- The response of a barrier to a tropical or extratropical cyclone has to be appreciated in a longer temporal context involving morphological preconditioning due to antecedent wave and water-level conditions.

- A useful way to visualise and conceptualise more complex storm behaviours and the longer-term vulnerability of barriers is the 'resilience trajectory', which maps out the changes in barrier geometry (elevation and width).

- An increased understanding of barrier response to storms and sequences of storms is required to better quantify long-term barrier response to climate change and high-resolution and comprehensive decadal records of barrier response to storms are a prerequisite to achieve this ambition.

\begin{abstract}
Wave-dominated and mixed-energy barriers are extremely dynamic landforms, responding to processes operating over a spectrum of time scales, ranging from daily-to-monthly fluctuations related to storm and post-storm conditions, to century-to-millenniumscale evolution driven by relative sea-level change. Two types of storm are of particular relevance: warm-core tropical and coldcore extratropical cyclones. Both are responsible for generating very large waves, highly energetic surf zone dynamics and sediment transport, elevated inshore water levels, and extensive morphological responses. All cyclones are affected by climate change, which governs their frequency, intensity and tracks.
\end{abstract}

Barrier storm response is primarily governed by maximum storm runup and barrier morphology, as conceptualised in Abby Sallenger's Storm Impact Scale model. This model defines four storm-impact regimes and includes erosive as well as accretionary responses. On the erosion side, the swash regime drives bar and berm flattening; the collision regime is marked by dune scarping and beach lowering; the overwash regime leads to dune scouring and channel incision; and the inundation regime may result in barrier destruction. On the deposition side, storm berms and beach ridges may form and accrete in the swash and collision regimes; localised vertical beach and barrier accretion are associated with the collision and overwash regimes; and washover deposition takes place in the overwash and inundation regimes. Site-specific factors play a key role in moderating the morphological response and include storm characteristics (type, duration and track), longshore sediment supply, upwelling-downwelling currents, coastal setting and inner-shelf topography.

The response of a barrier to a tropical or extratropical cyclone can, however, not be considered in isolation and has to be appreciated in a longer temporal context involving morphological preconditioning due to antecedent wave and water-level conditions. Additionally, a simple process-response approach of the cause-and-effect type is inappropriate and a more complex conceptual framework, involving thresholds, feedbacks, resilience and vulnerability, will need to be adopted. A useful way to visualise and conceptualise more complex storm behaviours and the longer-term vulnerability of barriers is the "resilience trajectory', which maps out the changes in barrier geometry (elevation and width) over various time scales, from weeks to years or even longer, and under varying forcing conditions, including changes in storminess and sea-level rise.

An increased understanding of barrier response to storms and sequences of storms is required to better quantify long-term barrier response to climate change. High-resolution and comprehensive decadal records of barrier response to storms are a prerequisite to achieve this ambition, linking site-specific coastal settings, hydrodynamic drivers and morphological responses, and allowing the recognition of recovery- and impact-dominated phases. The enhanced insights in barrier response to extreme events must then be incorporated into improved coastal response models to help predict the impacts of future climate change on wave-dominated and mixed-energy barriers around the world.

\title{
Keywords
}

Beaches; dunes; barriers; overwash; storms; cyclones; coastal response; sea-level rise 


\section{Introduction}

Wave-dominated and mixed-energy barriers occur in a wide range of settings. Their distribution and types are governed by various environmental boundary conditions, including hydrodynamic forcing (wind, waves and tides), sediment characteristics (abundance and grain-sise distribution), offshore bathymetry, tectonic setting and (relative) sea-level history (e.g., Roy et al., 1994; Figure 1). Constructed out of loose material and located in energetic wave-influenced environments, barriers are extremely dynamic landforms. Their seaward and landward margins migrate significantly over a wide spectrum of time scales, ranging from wave- and tide-controlled hourly and daily fluctuations to century- or millennium-scale evolution driven by relative sea-level change.

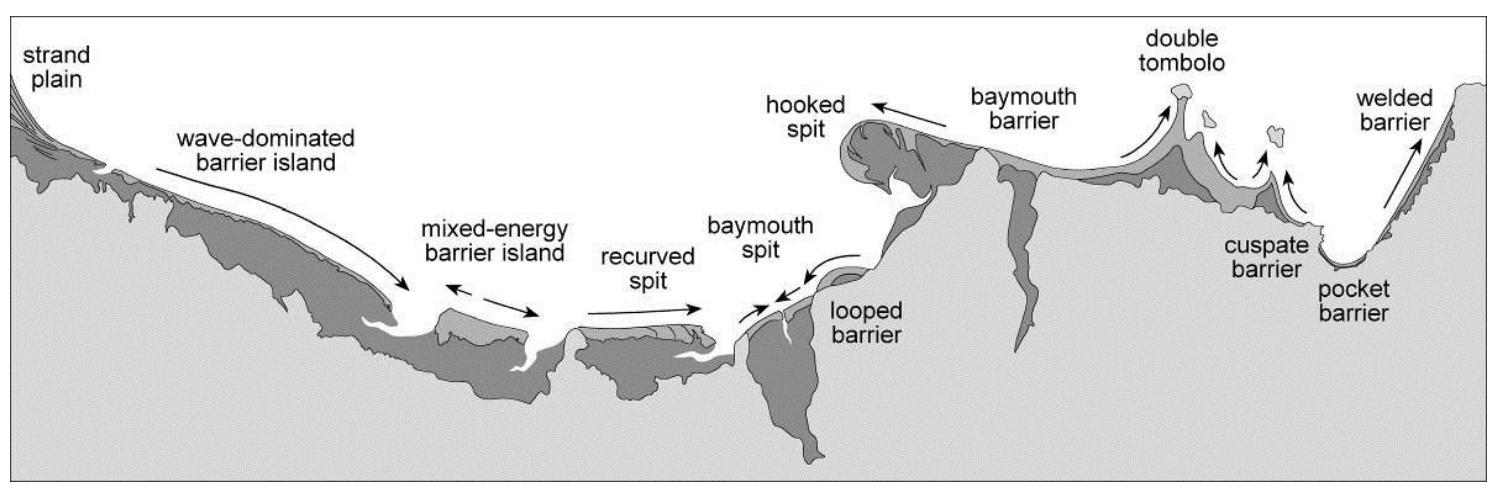

Figure 1 - Main barrier types. Attached forms include welded barriers, pocket barriers, cuspate barriers, double tombolos, baymouth barriers and various spits. Detached forms are mixed-energy and wavedominated islands. Strand plains are characterised by a multiple-barrier planform in a progradational setting. Arrows denote littoral drift and dark shading represents submerged and low-lying back-barrier areas. Source: Van Heteren (2014).

Regardless of the time scale under consideration, storm-induced extreme wave and water-level conditions are key drivers of barrier dynamics. They are associated with the largest morphological responses and changes in shoreline position. Single storms can result in meters of shoreline change within hours. A sequence of storms, for example during a winter season, may cause a seasonal, cumulative shoreline response (Komar, 1998). Over longer time scales, storminess-driven coastal change is marked by annual variability (e.g., caused by El Nino / La Nina), by decadal cycles associated with atmospheric teleconnections (e.g., North Atlantic Oscillation NAO), and by century-scale periodicity linked to climatic changes (e.g., Little Ice Age). Even in the long term, barrier erosion and retrogradation are far from gradual processes. Most barriers are characterised by periods of relative stability punctuated by short-lived change. The landward migration of transgressive barrier systems, although governed by rising sea level operating over centuries to millennia, is accomplished during individual storms and other, less energetic, wind-driven events. It could even be argued that without the elevated wave and water-level conditions associated with these events, barrier systems would lack the capability to cope with sea-level rise and would simply drown.

Meteorologically, storms are easy to define by factors such as maximum sustained wind speed, lowest atmospheric pressure or largest pressure drop over a certain amount of time. Similarly, from a purely oceanographical point of view, storms can be defined as distinct events during which waves exceed a certain height and/or energy threshold for a certain amount of time (e.g., Lemm et al., 1999). Storm groups can then be defined as sequences of individual storms separated by maximum time intervals of non-storm conditions. However, a storm definition based on a wave-height threshold (e.g., maximum significant wave height $H_{s}$ ) is highly site-specific, and depends strongly on the modal wave conditions. For a sheltered barrier, $H_{s}>2 \mathrm{~m}$ might be considered a storm (e.g., Houser and Greenwood, 2005), whereas for an exposed barrier, $H_{s}=5 \mathrm{~m}$ might be the lower limit. From a marine geological point of view, a more appropriate approach to defining storms, identifying storm thresholds and investigating storm statistics might be to consider hydrodynamic forcing (wave conditions and water level) in the context of coastal change. Such approach is more useful to coastal managers (e.g., Gervais et al. 2012). It was followed in the EU-funded MICORE project (https://www.micore.eu/) and resulted in several site-specific storm definitions applicable to a number of coastal sites in Europe (e.g., Almeida et al., 2012; Armaroli et al., 2012; Del Rio et al., 2012; Haerens et al., 2012; Trivonova et al., 2012). Clearly, there is a disconnect between the purely meteorological/oceanographical storm forcing and the ensuing coastal response, and they must be considered in concert when investigating coastal impacts of storms.

Two types of storm are of particular relevance to barriers: warm-core tropical and cold-core extratropical cyclones (Figure 2); both are responsible for generating highly energetic wave conditions and elevated inshore water levels. Tropical cyclones (TC) are non-frontal low-pressure systems that develop over tropical or subtropical oceans. Depending on location, the highest-intensity TCs are referred to as 'hurricanes', 'typhoons', '(severe) tropical cyclones' or 'severe cyclonic storms'. Hurricanes are further subdivided into 5 categories on the basis of wind speed (Saffir-Simpson Hurricane Wind Scale SSHWS). Category 5 Hurricanes (maximum sustained wind speeds $>69 \mathrm{~m} \mathrm{~s}^{-1}$ ) represent the most severe TC with the strongest winds, the lowest atmospheric pressures, the largest waves and the highest storm surges. Since 1924, 13 of the 35 recorded Category 5 Hurricanes that made landfall in the USA did so at maximum strength. 
Extratropical or mid-latitude cyclones (ETC) are frontal systems that evolve along the polar front, which is defined as a semicontinuous boundary in the mid-latitudes that separates cold polar from warm subtropical air masses (Figure 2). The more general terms 'depressions' and 'lows', sometimes with the adjective 'frontal' are commonly used. ETCs are generally associated with significantly less extreme wave and water-level conditions than TCs. Compare, for example the maximum storm surge of $3.5 \mathrm{~m}$ during the 1953 North Sea flood, associated with the region's most devastating storm of the twentieth century (Wolf and Flather, 2005), with surge values up to 8.5 m during Hurricane Katrina in 2005 (Fritz et al., 2007).

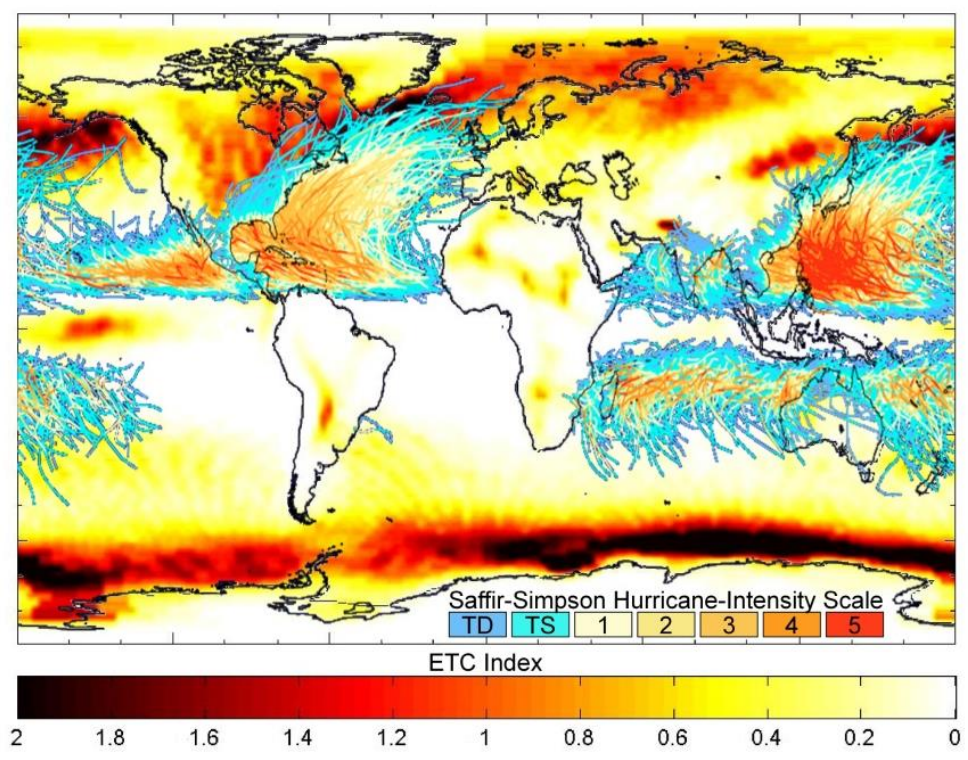

Figure 2 - $\quad$ TC tracks observed during the last 150 years (http://eoimages.gsfc.nasa.gov/images/imagerecords/7000/7079/tropical_cyclone_map_lrg.gif),

plotted on a map showing the global frequency of ETCs for the period 1961-1998 (http://data.giss.nasa.gov/stormtracks/). The TC overlay is based on all storm tracks available from the National Hurricane Center and the Joint Typhoon Warning Center through September 2006. The accumulation of tracks reveals where the most severe storms form and which large-scale atmospheric patterns influence their tracks. TD and TS refer to tropical depressions and tropical storms, respectively, and numbers 1 to 5 refer to Category 1 to 5 Hurricanes. The ETC base map is an aggregation of year-round data from the NCEP/NCAR Reanalysis Project. The greatest frequency of ETCs (reds) occur along the path of warm ocean currents that follow the eastern seaboards of North America and Asia. These warm, poleward-moving currents create large temperature contrasts with the cold winter-time continents and supply energy that helps generate and strengthen storm systems. Note that a similar pattern of storms circumnavigates the cold continent of Antarctica. The scale used for the ETC frequency plot represents the percentage of time that a low-pressure centre (i.e., a storm) was found over a given location from 1961 to 1998. Note the relatively calm regions in South America and the southwest coast of Africa, but also note that large waves generated elsewhere may affect these coastlines.

This paper will review progress made in the last decade in our understanding of barrier response to extreme wave and water-level conditions caused by TCs and ETCs. An overview of short- and long-term influences as well as key hydrodynamic drivers determining storm-related barrier behaviour provides the framework needed to understand various types of destructive and constructive barrier response to individual storms. We build on Sallenger's (2000) impact scale of barrier response to hurricanes, placing beach change, dune erosion, overwash, breaching and destruction in a context of pre-storm conditioning and post-storm recovery. Understanding barrier response to storms requires fully integrated long-term monitoring series, laboratory experiments and numerical modelling of drivers and coastal change.

\section{Long-term influences: sea-level change and storminess}

Sea-level change is the key driver for longer-term barrier evolution and owing to global warming most barriers are affected by relative sea-level rise. The global rate of sea-level rise estimated from (satellite) altimetry data over the 15-year period from 1993 to 2008 is $3.5 \mathrm{~mm} \mathrm{yr}^{-1}$ (Nicholls and Cazenave, 2010), but according to most global sea-level data sets the rate of sea-level rise is accelerating (Church and White, 2011) and may approach rates experienced during the early and mid-Holocene periods (5-10 $\mathrm{mm} \mathrm{yr}^{-1}$; Woodroffe and Murray-Wallace, 2012) by the end of this century. Following their analysis of sea-level rise and its possible coastal impacts given a 'beyond $4^{\circ} \mathrm{C}$ world', Nicholls et al. (2011) provided a pragmatic estimate of the sea-level rise by 2100 between 0.5 and $2 \mathrm{~m}$. Sea-level rise due to climate change will induce an upward shift in storm-related maximum water levels and will shorten the return intervals of specific record levels (e.g., Fiore et al., 2009). In turn, this will enhance the impact of storms on barriers by increasing both the potential for coastal flooding and the severity of barrier erosion (Zhang et al., 2002). 
In addition to its effect on eustatic sea level, global warming is also expected to enhance climate variability, and therefore the occurrence of weather extremes, wave conditions and water levels. Clustered extreme storms result in cumulative effects on barrier behaviour. When beaches and dunes are unable to fully recover from storm impact, they become increasingly vulnerable. Therefore, past storminess variations must be considered to understand long-term barrier stability, and future storminess trends need to be forecasted accurately to predict long-term barrier behaviour. Numerous studies have been conducted to quantify temporal changes in storminess over the past 50-100 years and to link these to climate change (e.g., Keim et al., 2004; Grossmann and Granger Morgan, 2011). As yet, there is no agreement on causes of past storminess trends, however, making it difficult to assess and understand the contributions of changing climate or ocean currents. The presumed increasing trend in TC activity (Webster et al., 2005; Emanuel, 2007), for example, can largely be ascribed to observation bias due to imperfect sampling in the pre-satellite era (Vecchi and Knutson, 2011; Figure 3). Other uncertainty arises from large-amplitude natural variations in the frequency and intensity of extreme storm conditions (e.g., TC activity is related to the Atlantic Multi-decadal Oscillation (AMO); ETC activity is related to the North Atlantic Oscillation (NAO)). An additional problem in interpreting trends in cyclonic activity is that both TC and ETC tracks are not fixed in space. Spatial shifts over time may regionally increase or decrease storminess, as demonstrated, for example, by Wu et al. (2005) for the shifting typhoon influence in the South China Sea and by Alexander et al. (2005) for opposite changes in storm frequency in Iceland and the UK due to a shift in position of the North Atlantic storm track.

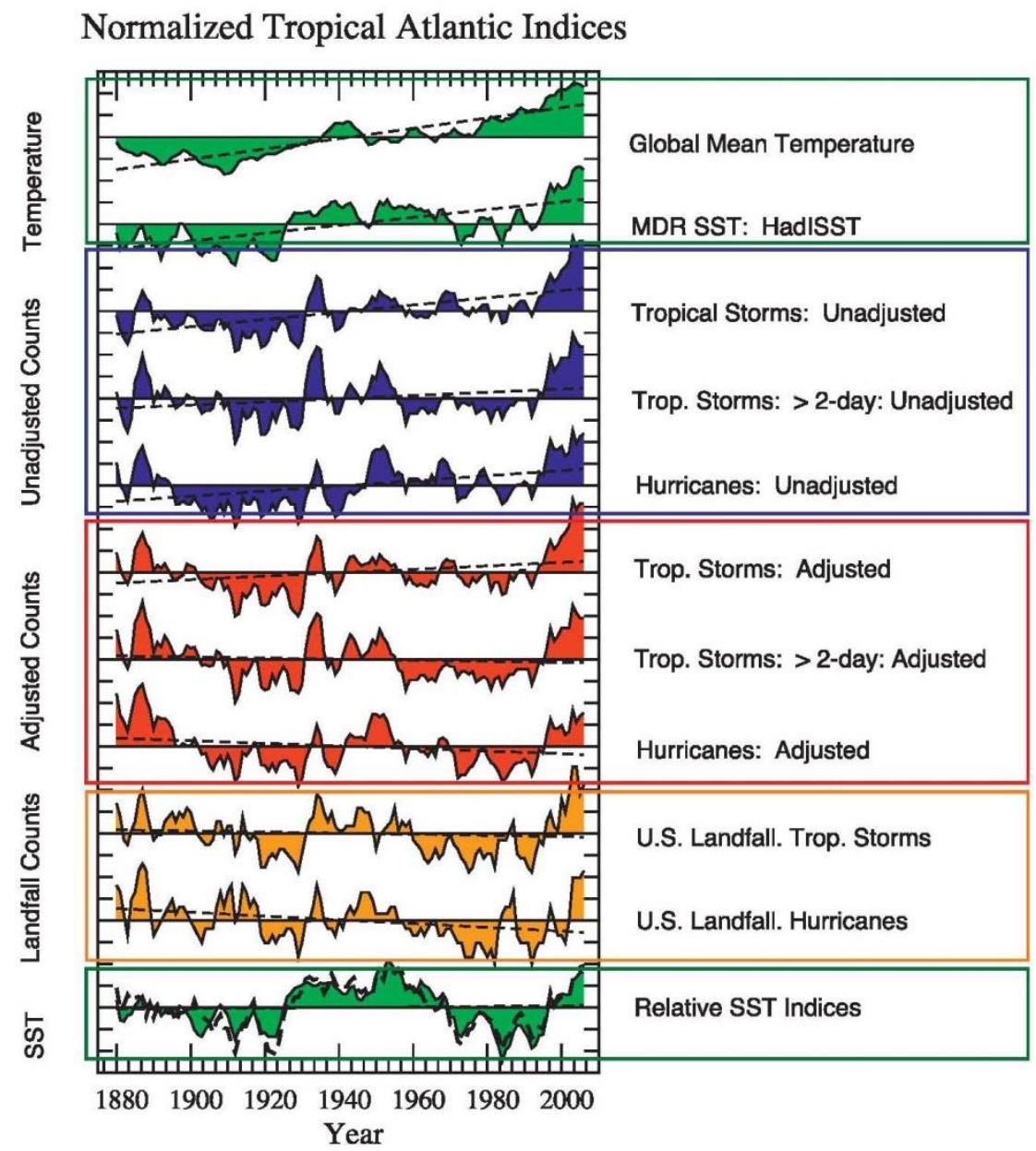

Figure 3 - Time series of indices relevant to changing Atlantic tropical cyclone activity. Filled lines indicate the normalised 5-yr running means during 1878-2008 with straight dashed lines indicating the linear least-squares trends. Green-shaded curves depict global mean temperature, sea-surface temperature (SST) in the main development region (MDR) of the cyclones, and the relative SST (MDR minus tropical mean); blue-shaded curves represent unadjusted tropical storm and hurricane counts; red-shaded curves represent adjusted tropical storm and hurricane counts; and orange-shaded curves depict U.S. landfalling tropical storms and hurricanes (no adjustments - not required). Vertical axis ticks represent one standard deviation, with all series normalised to unit standard deviation after a 5yr running mean was applied. Only the top two temperature series, the unadjusted tropical storms of all duration and the unadjusted hurricane frequency series have significant linear trends $(\mathrm{p}=0.05)$. Note that the adjusted hurricane count is more strongly connected to the difference between MDR SST and tropical-mean SST than with MDR SST in itself. These results do not support the hypothesis that the warming of the tropical North Atlantic due to anthropogenic greenhouse gas emissions has caused Atlantic hurricane frequency to increase. Source: Vecchi and Knutson (2011). 
The formation of TCs is strongly related to the ocean water temperature. For example, the 2005 North Atlantic hurricane season was the stormiest year on record (e.g., Virmani and Weisberg, 2006), featuring 4 Category 5 as part of 15 total hurricanes (Figure 3). During that year, sea-surface temperatures (SSTs) in the tropical North Atlantic region critical for hurricanes $\left(10^{\circ}\right.$ to $20^{\circ} \mathrm{N}$ ) were at record highs in the extended summer (June to October), $0.9^{\circ} \mathrm{C}$ above the $1901-70$ normal. This positive temperature anomaly was attributed mainly to the global rise in SST and thus to global warming (Trenberth and Shea, 2006). However, the link between global warming and TC activity has not been that straightforward and Knutson et al. (2010) have summarised the state of the science by concluding that the frequency of the most intense TCs will more likely than not increase due to climate change in the future, but the global frequency of all lower-intensity TCs will either decrease or remain essentially unchanged in response to global warming (Meehl et al. 2007; Walsh et al., 2012). Changes in storminess due to ETCs are even more difficult to model because their generation is less obviously linked to factors such as SSTs, and are more likely influenced by complicated atmospheric teleconnections (Woolf et al., 2002; Betts et al., 2004; Osborn, 2004; Tsimplis et al., 2005). Accordingly, consensus is lacking for predictions in changes in ETC storminess; for example, Lambert and Fyfe (2006) predict a reduction in the total number of storm events, an increase in the number of high-intensity events, and no obvious shift in storm tracks associated with global warming for the UK, whereas Lowe et al. (2009) predict a southward movement of the storm tracks and a small decrease in wave height to the north of the UK and some slight increases in wave height in most southerly regions, as well as a southward shift in the storm tracks.

\section{Factors influencing the impact of individual storms}

Barrier response to individual storms is site-specific and complex. It is controlled by multiple factors related to storm track and intensity, tidal phase and amplitude, cross-shore and longshore morphology of the coastal tract (interrelated cross-shore sequence of coastal morpho-sedimentary sub-units, as defined by Cowell et al. (2003)), sediment supply, barrier volumes (buffers), sediment type, vegetation, and even sea ice and groundwater.

The intensity of individual storms is governed by their energy, size, track, and speed of forward motion (Penland et al., 1989). Energy controls maximum wind speeds; storm size and speed are linked to duration; and track relative to coastal orientation determines whether, where and under which angle a storm makes landfall. For each coastal section, these four elements are the principal drivers of waves, currents and surges that are modified by shoreface and nearshore morphology before impacting barriers. Other factors aside, large and slow-moving storms have a greater effect than small, rapidly moving storms (e.g., Claudino-Sales et al., 2008), landfall position influences erosion intensity (e.g., Claudino-Sales et al., 2010), and shoreperpendicular impact causes more damage than oblique impact (Wang et al., 2006; Fritz et al., 2007). Interestingly, the swell of some hurricanes that do not make landfall can move large volumes of sand to shore, as illustrated by the accretion of many midAtlantic US beaches during Hurricane Felix in 1996 (Zhang et al., 2002). Water levels associated with storm-driven surge and runup are highest when the storms coincide with perigean spring tides. Timing is especially important for areas where surge amplitudes are relatively small when compared to tidal range (Anthony, 2013).

Shelf width exerts a substantial morphological control over storm-related barrier behaviour. Wind-driven surges superimposed on spring tides are more important on coasts fringing wide shelves, whereas storm-wave height has a tendency to dominate over tidal effects on coasts with narrow shelves. Closer to shore, shoreface and nearshore morphology modulates storm impact in different ways, as summarised by Anthony (2013). Firstly, ridges and other highs (such as ebb-tidal deltas, longshore bars) reduce the shoreward transfer of wave energy by spatially and temporally variable storm-wave refraction and diffraction (e.g., O'Reilly and Guza, 1993); and secondly, ridges and bars may weld to shore and thus act as a sediment source. Intricate morphologies result in complex coastal storm responses (Regnauld et al., 2004). Accretion is most likely where sediment is plentiful and morphological highs are close to shore (Aernouts and Héquette, 2006). Fire Island (New York) is a good example of how inner-shelf geology and morphology affect storm-induced barrier response. Here, differences in offshore slope gradients and large-scale bedforms, coupled with island orientation, explain measured behavioural differences between the east and west reaches of the barrier island (Lentz et al., 2013).

The availability of sediment from offshore and longshore sources cannot be ignored when storm impact is assessed (e.g., Héquette and Ruz, 1991), even when recovery is not considered. High sediment supply has a direct bearing on barrier volume and thus on short- and long-term resilience. Low sediment supply is a key element in barrier narrowing (Timmons et al., 2010) and may lead to beach steepening when storm-generated runup transports mid-beach coarse-grained sediment both toward the beach crest and seaward (Orford et al., 2002). Sediment from sources as diverse as coral reefs and ebb-tidal deltas is transported to the subaerial barrier not only through the episodic welding of ridges and bars, especially during storms (e.g., Aagaard et al., 2007), but also by longshore processes (e.g., Lapinskis, 2005). Temporarily wide intertidal areas become subject to strong winds that further redistribute sand-sised material (e.g., Anthony, 2013). During storms, this aeolian reworking process is limited, except when associated surges are superimposed on neap tides or spring lows and thus leave part of wide, dissipative beaches dry and exposed (Houser, 2009).

Over longer time scales, sediment availability from longshore and cross-shore sources is one of the elements affecting subaerial barrier morphology, a key factor when considering storm impact. The most important subaerial morphological aspects are beach width and slope, height and continuity of the foredune ridge, width of the primary and secondary dune area, and inlet presence. Aside from exposing sand to aeolian transport, wide and gently sloping beaches cause wave dissipation and limit wave runup. 
Low-lying barriers are much more vulnerable to overwash and inundation (Dingler and Reiss, 1995) and high, continuous dune ridges are the first line of defence for a coastal barrier, especially when vegetated. Even when being eroded by scarping, intact frontal dunes or closely spaced primary and secondary dunes prevent overwash and further damage to the barrier (Houser et al., 2008). Sediment eroded from the dunes will also form a buffer in front of the remaining dunes, providing further protection from overtopping and overwash. Barrier resilience and survival during storms is more strongly controlled by dune width than by dune height (Claudino-Sales et al., 2010), because wide dunes tend to be more voluminous, requiring more time or higher wave energy to erode. Inundation and destruction are, therefore, much more likely along narrow barrier sections, especially when weakly rooted incipient dunes dominate. Only the longest-duration storms are capable of lowering and narrowing wide barriers enough to be inundated and destroyed (Donnelly, 2007). When frontal dunes of wide barriers are eroded, interior wetlands provide accommodation space for perched washover fans flanking secondary dunes, limiting loss of sediment to back-barrier areas (Claudino-Sales et al., 2008). In coarse-grained systems, crest accumulation is more likely for wider ridges, which limit erosive overwash, than for narrower ones (Donnelly, 2007). Under these conditions, enhanced hydraulic conductivity results in substantial swash infiltration, which limits overwash (McCall et al., 2012) and encourages crest deposition.

The grain size and shape of barrier sediment determine how much force is needed to mobilise sediment. They are also linked to beach permeability and slope. During storms, the high permeability and bed roughness of coarse-grained beaches contribute strongly to wave dissipation, but their steep slopes are conducive to higher ratios between runup $R$ and offshore wave height $H$ (typically $R / H>1$ for gravel) than the gentler slopes of sandy beaches (typically $R / H<1$ ). Generally, the presence of gravel constrains barrier-crest elevation and makes it harder for water to overwash and erode the crests (Bradbury and Powell, 1993; Orford et al., 2002). The characteristics of material underlying barriers are also important. Erosion of muddy deposits may undermine and destabilise overlying beaches and barriers, whereas barriers fronted by coarse sediment are marked by added stability (Shaw et al., 1993). Models show that poorly compacted sediment in deltaic areas leads to barrier sinking and may thus amplify storm impact (Rosati et al., 2010).

Through its stabilizing effects, vegetation contributes to the resilience of barriers during storms. Both vegetation density and type should be considered. Marram grass, for example, reduces erosion and assists in dune recovery (Godfrey et al., 1979; Wolner et al. 2013), helping to maintain and restore high dunes and limiting overwash to only severe storms. Cordgrass, on the other hand, occupies frequently activated overwash channels and flats (Hosier and Cleary, 1977; Godfrey et al., 1979). It is able to regenerate through thick washovers (Ehrenfeld, 1990), resulting in stabilization, but deters dune building (Godfrey and Godfrey, 1976; Stallins, 2005). Densely wooded dune fields are more resistant to erosion than dunes vegetated with grass (Claudino-Sales et al., 2008). Behind or in front of barriers, dense mangrove swamps dissipate overwash energy more effectively than salt marshes (Wang and Horwitz, 2007).

\section{Hydrodynamic processes during storms}

The two main elements in barrier response to storms are pre-storm state, as determined by various short- and long-term factors, and hydrodynamic processes. The latter include storm surges, wave conditions, and near-coastal currents. Their absolute values do not necessarily matter, as these are site-specific, but what counts is the deviation from fair-weather values.

\subsection{Storm surge}

Storms are characterised by strong winds and low atmospheric pressure, and these generate a positive storm surge, defined as the difference between the recorded water level and that predicted by the astronomical tide (the term 'skew surge' is used for the difference between the maximum water level recorded during a tidal cycle and the high-tide level). Surge-generating forces include the static effects of atmospheric pressure acting upon the sea surface, the tractive force of winds setting water in motion, and dynamic effects that impinge upon these forces by virtue of the speed of the cyclone system (Betts et al., 2004). Further controls on the resulting storm surge are the coastal and shelf configurations. Shoreline indentations, especially funnel-shaped bays and basins, amplify open-ocean storm surges, whilst promontories suppress their development (Figure 4). Paradoxically, the shelf conditions that favour high storm surges tend to attenuate the contribution of waves, and the shelf conditions that act to attenuate storm surges allow a larger contribution of waves (Walsh et al., 2012). Wide and gently sloping continental shelves are the most conducive to high storm surges.

\subsection{Surf zone hydrodynamics}

The principal effect of storm winds is the generation of high waves, commonly with long periods. In the open ocean, significant wave heights exceeding $10 \mathrm{~m}$ are not uncommon during the most severe storms. Such wave heights may even be experienced directly along rocky coastlines, as testified by the existence and regular modification (at least once every few years) of cliff-top mega-clast deposits on islands along the exposed Atlantic coastline of Ireland (Hall et al., 2006), Scotland (Hall, 2011) and Brittany (Fichaut and Suanez, 2011). Because of friction and refraction, storm waves lose much of their energy traversing the inner continental shelf and shoreface (Figure 5). By the time storm waves close in on coastal barriers and break over sandy and gravelly substrates, they very rarely exceed $8 \mathrm{~m}$. Storms affect other wave and surf-zone parameters as well. Table 1 lists values for a number of these variables, comparing storm-associated, moderately energetic and calm conditions. 


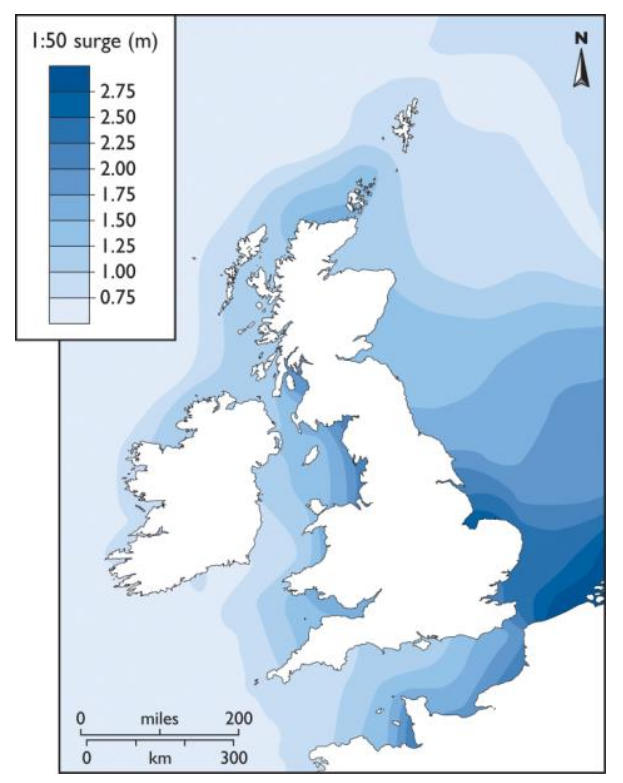

Figure 4 - Magnitude of a 1-in-50-year storm surge around Great Britain and Ireland. Source: Flather (1987).
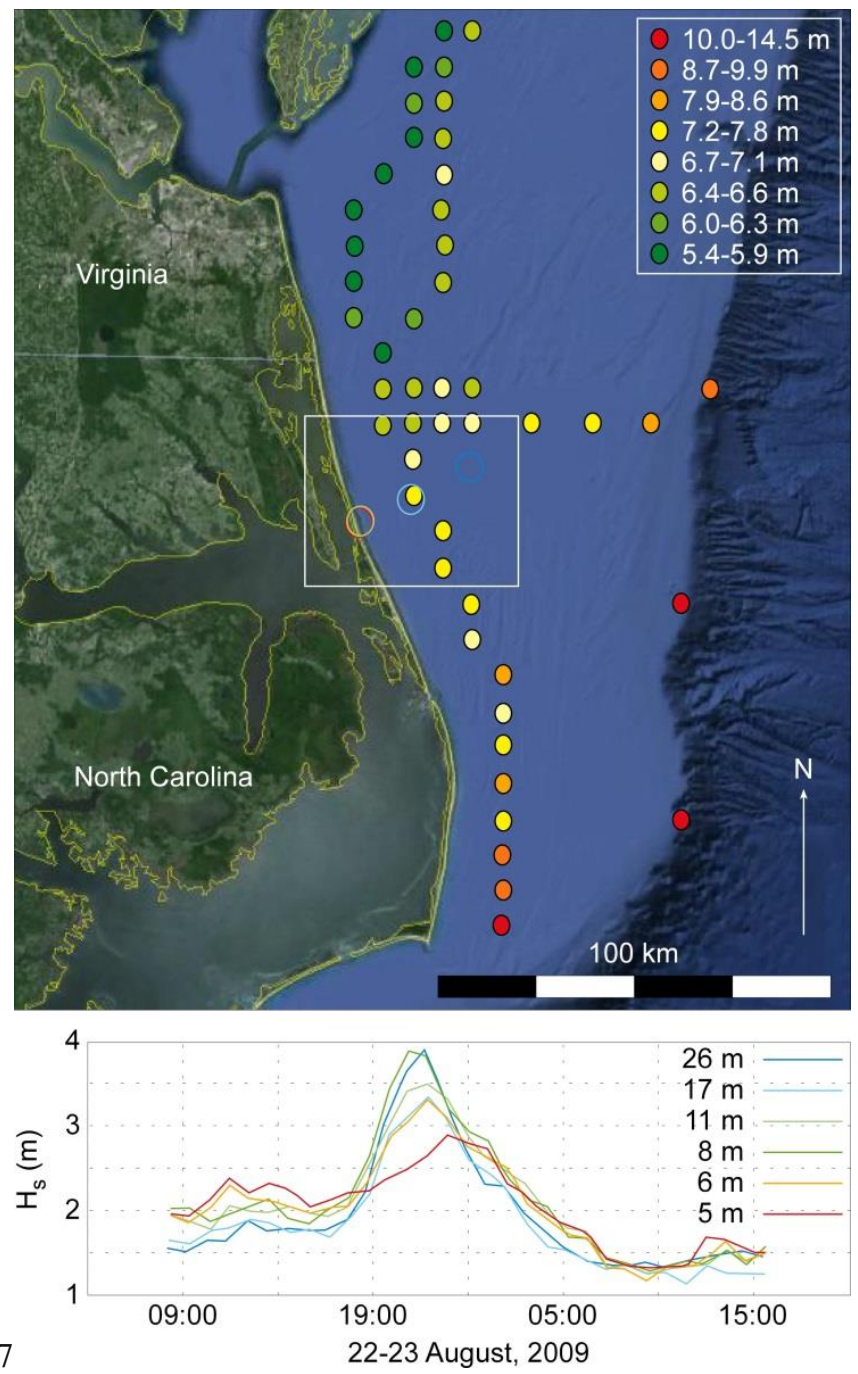

Figure 5 -Predicted significant wave height $\mathrm{H}_{\mathrm{s}}$ for 100-year recurrence interval ETC for coastal North Carolina and Virginia (upper panel). Comparison between offshore and nearshore wave conditions off the coast of North Carolina over a 2-day period in August 2009, when Hurricane Bill passed the area without making landfall (lower panel; for location, see inset in upper panel). Before the storm arrived, shoaling resulted in a landward increase in wave height, whereas during the storm, energy dissipation by bed friction and refraction caused a landward decrease in wave height. Source: Forte et al. (2012) (upper panel); Hanson et al. (2009) (lower panel). Plotted on GoogleEarth map. 
Table 1 - Typical beach, wave and surf-zone parameters for calm, energetic and extremely energetic wave conditions.

\begin{tabular}{|c|c|c|c|}
\hline Parameter & $\begin{array}{l}\text { Calm wave } \\
\text { conditions }\end{array}$ & $\begin{array}{l}\text { Energetic wave } \\
\text { conditions }\end{array}$ & $\begin{array}{l}\text { Extreme storm } \\
\text { conditions }\end{array}$ \\
\hline \multicolumn{4}{|l|}{ Beach boundary conditions } \\
\hline Beach gradient $\tan \beta(-)$ & 0.06 & 0.04 & 0.02 \\
\hline Sediment size $D_{50}(\mathrm{~m})$ & 0.004 & 0.003 & 0.002 \\
\hline Sediment-fall velocity $w_{s}\left(\mathrm{~m} \mathrm{~s}^{-1}\right)$ & 0.05 & 0.04 & 0.03 \\
\hline \multicolumn{4}{|l|}{ Wave-forcing parameters } \\
\hline Breaking-wave height $H_{\mathrm{s}}(\mathrm{m})$ & 0.5 & 2 & 8 \\
\hline Wave period $T(\mathrm{~s})$ & 6 & 8 & 10 \\
\hline Breaking-wave angle $\alpha\left(^{\circ}\right)$ & 10 & 10 & 10 \\
\hline \multicolumn{4}{|l|}{ Morphodynamic indices } \\
\hline $\begin{array}{l}\text { Wave length (m) } \\
L_{o}=\frac{g T^{2}}{2 \pi}\end{array}$ & 56.18 & 99.87 & 156.05 \\
\hline $\begin{array}{l}\text { Surf similarity parameter (-) } \\
\xi_{b}=\frac{\tan \beta}{\sqrt{H_{b} / L_{o}}} \\
\text { Battjes (1974) }\end{array}$ & 0.64 & 0.28 & 0.09 \\
\hline $\begin{array}{l}\text { Surf scaling parameter (-) } \\
\varepsilon_{b}=\frac{H_{b}}{L_{o} \tan ^{2} \beta} \\
\text { Guza and Inman (1975) }\end{array}$ & 7.76 & 39.30 & 402.43 \\
\hline $\begin{array}{l}\text { Dimensionless fall velocity (-) } \\
\Omega=\frac{H_{b}}{w_{s} T} \\
\text { Wright and Short (1984) }\end{array}$ & 1.67 & 6.25 & 26.67 \\
\hline \multicolumn{4}{|l|}{ Wave runup } \\
\hline $\begin{array}{l}\text { Wave setup (m) } \\
\eta=1.1\left(0.35 \tan \beta \sqrt{H_{o} L_{o}}\right) \\
\text { Stockdon et al. (2006) }\end{array}$ & 0.12 & 0.22 & 0.27 \\
\hline $\begin{array}{l}\text { Maximum vertical swash excursion (m) } \\
S=1.1 \frac{\sqrt{\left[H_{o} L_{o}\left(0.563 \tan ^{2} \beta+0.004\right)\right.}}{2} \\
\text { Stockdon et al. (2006) }\end{array}$ & 0.23 & 0.54 & 1.26 \\
\hline $\begin{array}{l}\text { Maximum runup (m) } \\
R=\eta+S \\
\text { Stockdon et al. (2006) }\end{array}$ & 0.35 & 0.76 & 1.54 \\
\hline \multicolumn{4}{|l|}{ Nearshore currents and sediment transport } \\
\hline $\begin{array}{l}\text { Longshore current velocity }\left(\mathrm{m} \mathrm{s}^{-1}\right) \\
\bar{v}_{l}=1.17 \sqrt{g H_{b}} \sin \alpha_{b} \cos \alpha_{b} \\
\text { Komar and Inman }(1970)\end{array}$ & 0.44 & 0.89 & 1.77 \\
\hline $\begin{array}{l}\text { Mean bed return flow velocity }\left(\mathrm{m} \mathrm{s}^{-1}\right) \\
\bar{u}=0.16 \sqrt{H_{b}} \\
\text { Masselink and Black (1995) }\end{array}$ & 0.11 & 0.23 & 0.45 \\
\hline $\begin{array}{l}\text { Littoral drift }\left(\mathrm{kg} \mathrm{s}^{-1}\right) \\
Q_{l}=3.82 T_{p}^{1.5} \tan \beta^{0.75} D_{50}^{-0.25} H_{b}^{2}\left(\sin 2 \alpha_{b}\right)^{0.6} \\
\text { Kamphuis (1991) }\end{array}$ & 3.55 & 69.42 & 1021.38 \\
\hline
\end{tabular}

Individual waves will break in water depths 1.2-1.5 times greater than the height at the moment of breaking. Thus, waves higher than $8 \mathrm{~m}$ will typically start breaking far offshore (>1 km). Waves may break intermittently over multiple nearshore bars or persistently as they propagate across the surf zone. The dissipative characteristics of surf zones can be parameterised by the 
Iribarren number $\xi$, the surf scaling parameter $\varepsilon$ and the dimensional fall velocity $\Omega$ (Battjes, 1974; Guza and Inman, 1975; Wright and Short, 1984; Table 1). By the time the incident waves reach the actual shoreline, almost all of their energy will have been lost by breaking. A significant part of the energy will have been transferred to lower-frequency infragravity waves, which have periods of 25 to $100 \mathrm{~s}$. In contrast to incident wave energy, infragravity-wave energy increases towards the shore and dominates the water motion in the inner surf and swash zones (Guza and Thornton, 1982) (Figure 6).

In addition to oscillatory wave and swash motions, mean nearshore currents (longshore currents and offshore-directed undertow currents) are also predicted to be strong under energetic wave conditions, $O\left(1-2 \mathrm{~m} \mathrm{~s}^{-1}\right)$ and $O\left(0.5 \mathrm{~m} \mathrm{~s}^{-1}\right)$, respectively (Table 1). The generation and dynamics of these currents are generally well understood (e.g., Garcez Faria et al., 1998, 2000); however, with the exception of Senechal et al. (2011a), all previous field measurements of nearshore currents were conducted when wave heights were less than $4 \mathrm{~m}$.
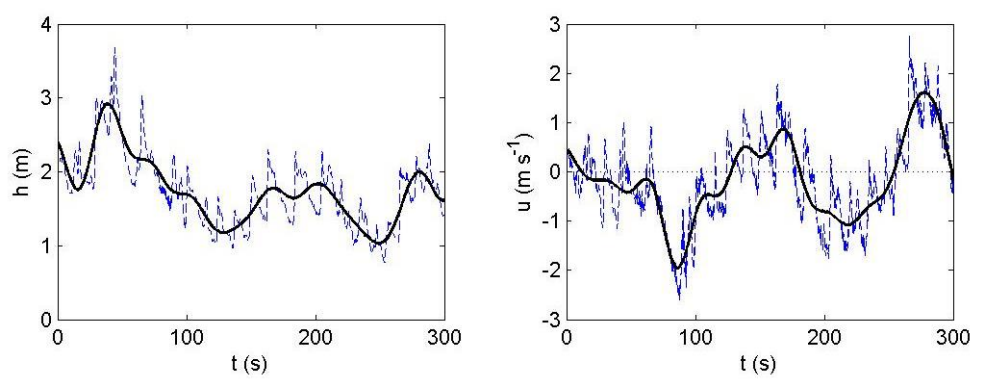

Figure 6 - Time series (5 minutes) of water depth $\mathrm{h}$ and cross-shore current velocity $\mathrm{u}$ recorded in the inner surf zone of a sandy beach during an extreme storm, with offshore significant wave height $\mathrm{H}_{\mathrm{s}}$ of 8 $m$ and significant wave period $\mathrm{T}_{\mathrm{s}}$ of $12 \mathrm{~s}$. The dashed line denotes the original time series and the thick solid line represents the lowpass-filtered time series using a 30-s filter. Note that the dominant time scale of the wave motion is 1-2 minutes, but that the incident waves are still discernible. Data were collected around 08:30 on 11 March 2008 at Truc Vert beach in France. Source: data from Ruessink (2010).

Wave runup is a key hydrodynamic parameter affecting coastal flooding and erosion, and is a function of the quasi-steady wave setup and the vertical extent of the fluctuating swash motion. The vertical runup excursion $R$ can be predicted with some confidence by the equations presented by Stockdon et al. (2006) (Table 1), but the formulations have not been validated for extreme wave conditions $\left(H_{s}>3 \mathrm{~m}\right)$. A recent field study by Senechal et al. (2011b) found a maximum, infragravity-dominated vertical swash motion of 2-2.5 m over a range of offshore wave conditions $\left(H_{s}=4-7 \mathrm{~m}\right)$, suggesting that under very energetic wave conditions even the infragravity swash motion is saturated (cf. Ruessink et al., 1998) and does not increase with additional intensification of wave forcing. Jointly, wave runup, astronomical tide and storm surge determine the maximum water level reached during a storm. As storm surges tend to climax on rising tides (Idier et al., 2012), peak water levels will be somewhat lower in practice than their maximum theoretical values for spring high tides. Maximum storm runup, so including tide and storm surge, can be derived from field observations of storm deposits and storm damage. Longshore variation in maximum wave runup shows clear large-scale patterns due to coastal orientation and topography, as illustrated for Hurricanes Camille (1996) and Katrina (2003) (Figure 7), and small-scale patterns due to nearshore morphology, as illustrated for a 2009 Northeast storm (Figure 8). 


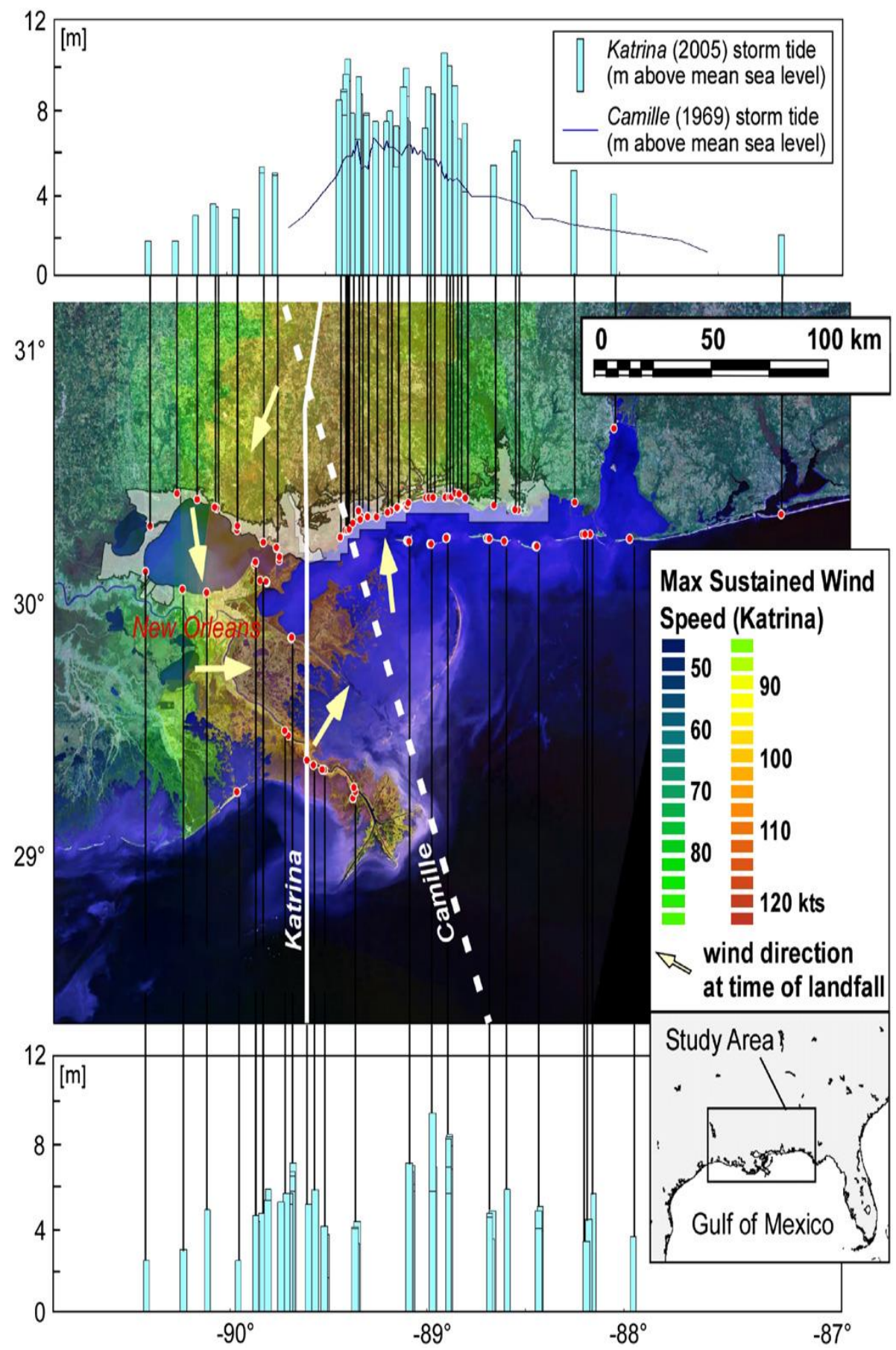

Figure 7 - Hurricane Katrina (2005; Category 3 at landfall) and Hurricane Camille (1969; Category 5 at landfall) storm-tide profiles. Hurricane Katrina storm-tide heights were determined from a wide variety of high-water marks left by the storm tide, which provide a record of the maximum runup, rather than the maximum difference between measured and predicted water level. Source: Fritz et al. (2007).

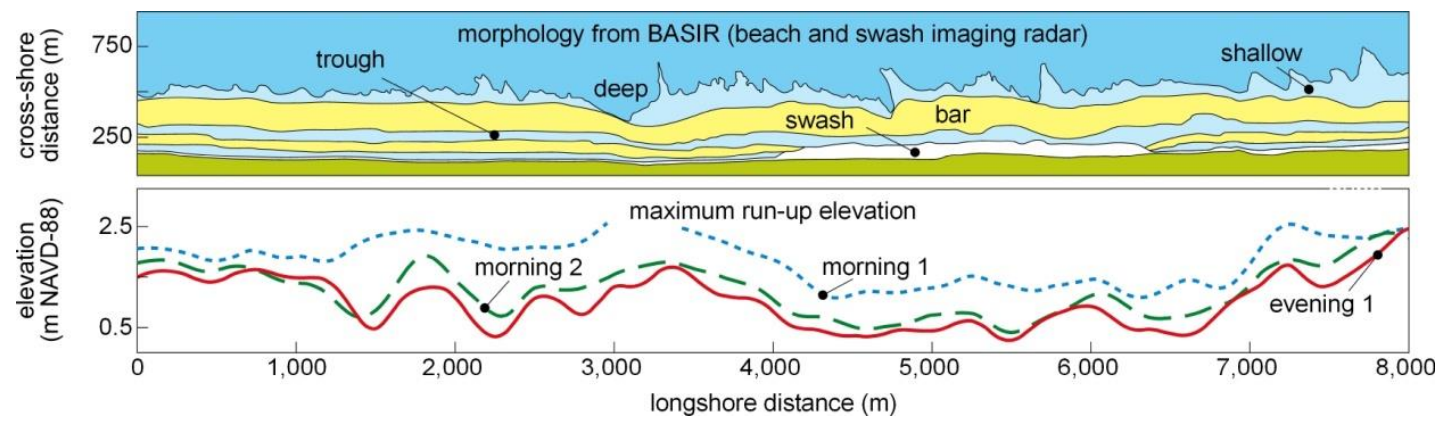

Figure 8 - Runup along an 8-km-long stretch of the North Carolina coastline showing small-scale variability caused by nearshore morphology. Source: Brodie and McNinch (2009). 


\subsection{Sediment fluxes and budgets}

Barrier response to storms involves both internal sediment redistribution and sediment exchange with adjacent environments in the coastal tract. Sand and gravel fluxes between barrier and back-barrier areas are mostly cross-shore and unidirectional, dominated by overwash of subaerial sediment to various protected intertidal and subaqueous environments. Where eroded subaerial sediment is deposited directly landward of the barrier, it remains part of the barrier and total mass is preserved despite an overall landward shift. Where overwashed sediment is transported into deeper water, it may be lost either temporarily or permanently (Donnelly et al., 2006). Sediment exchange with the nearshore, shoreface and inner shelf is more complicated, with bidirectional cross-shore and longshore components. In these subaqueous environments, highly energetic waves and strong nearshore currents have considerable sediment-transport capacity (Table 1).

The littoral drift rate under extremely energetic conditions computed using the Kamphuis (1991) equation is 2-3 and 1-2 orders of magnitude larger than under calm and moderately energetic conditions, respectively (application of other littoral drift equations would yield a similar outcome). This disproportionate increase (in relation to the actual wave height) is the combined result of enhanced wave stirring (and sediment resuspension), stronger longshore currents (and sediment advection) and a wider surf zone. Such a strong increase in sediment-transport potential also applies to cross-shore sediment fluxes; however, cross-shore sediment fluxes in the surf zone are made up of different components acting in opposing directions. For example, Conley and Beach (2003) found that while the mean component of storm-driven cross-shore sediment transport throughout the water column and across the surf zone was in the offshore direction because of the bed return flow, the incident wave-coherent component was onshoredirected (cf. Aagaard et al., 2012). The infragravity component, while exhibiting a definite offshore bias, was found to be negligible.

During 'normal' storms, sediments eroded from sandy beaches and dunes will remain in the nearshore zone and will not move much beyond the outer surf zone. In the reverse direction, little sediment is expected to be moved landward from the lower shoreface and inner shelf, as steady currents beyond the surf zone are unlikely to play a great part in redistributing all but the finest sediments. Shoaling waves, on the other hand, may induce onshore sediment transport; indeed, wave skewness is considered an essential process in the generation of nearshore bar morphology (Russell and Huntley, 1999; Marino-Tapia et al., 2007a, b). During extreme storms, the sediment budget of the combined beach and surf zone is no longer closed. Owing to an exceptionally widened surf zone, the bed return flow is able to transport sediments seaward to great depths, well beyond the 'normal' outer surf zone. The combination of extremely large waves, commonly with long periods, storm-surge ebb, and strong, wind-driven upwelling and downwelling currents creates sediment fluxes that extend well onto the inner continental shelf (e.g., Goff et al., 2010). Mega-rips are another important cross-shore cause of sediment transport far beyond the surf zone (Loureiro et al., 2012). They generate offshore-directed flows that can reach velocities up to $3 \mathrm{~m} \cdot \mathrm{s}^{-1}$ (Coutts-Smith, 2004) and are capable of transporting significant quantities of sediment all the way to the inner shelf (Short, 1985). Strong alongshore currents and sediment transport at great depth, finally, may cause lateral sediment exchange between adjacent coastal cells that cannot be reversed under non-storm conditions (List et al., 1991; Keen and Slingerland, 1993). The spatial changes in longshore transport cells that partly govern this sediment exchange are temporary and last only as long as the storm (Forbes et al., 2004). Permanent sediment loss of barriers is thought to occur when sand from dune, beach, nearshore zone and shoreface is transported so far offshore or alongshore that a return to the impacted coastal section is precluded or at least prolonged (e.g., Héquette and Hill, 1995). Thin active layers on many eroding shorefaces, as well as extensive sediment transport measurements, suggest that net sand loss from beach to shoreface is unlikely in many areas (Forbes et al., 2004; Ruggiero et al., 2010). Even the offshore redistribution of US Gulf Coast barrier sediments, as evident from extensive storm layers observed on the inner shelf following major storms (e.g., Hayes, 1967), may be temporary.

There are indications that onshore sediment transport may dominate during certain extreme storms, owing to upwelling currents. The Louisiana chenier plain, for example, is nourished by coarse sediment that is transported to shore during storms (McBride et al., 2007). On the Atlantic coast of the US, southwest storms commonly generate onshore-directed sediment transport (Wright et al., 1994; Hill et al., 2004) (Figure 9). In storms from other directions, a change from downwelling conditions to onshore sediment transport during the waning stage is no exception. Even when storm waves do not transport sediment all the way to the coast, deposition in shallow water leaves sand and gravel within reach of fair-weather transport processes (Xhardé et al., 2011). 


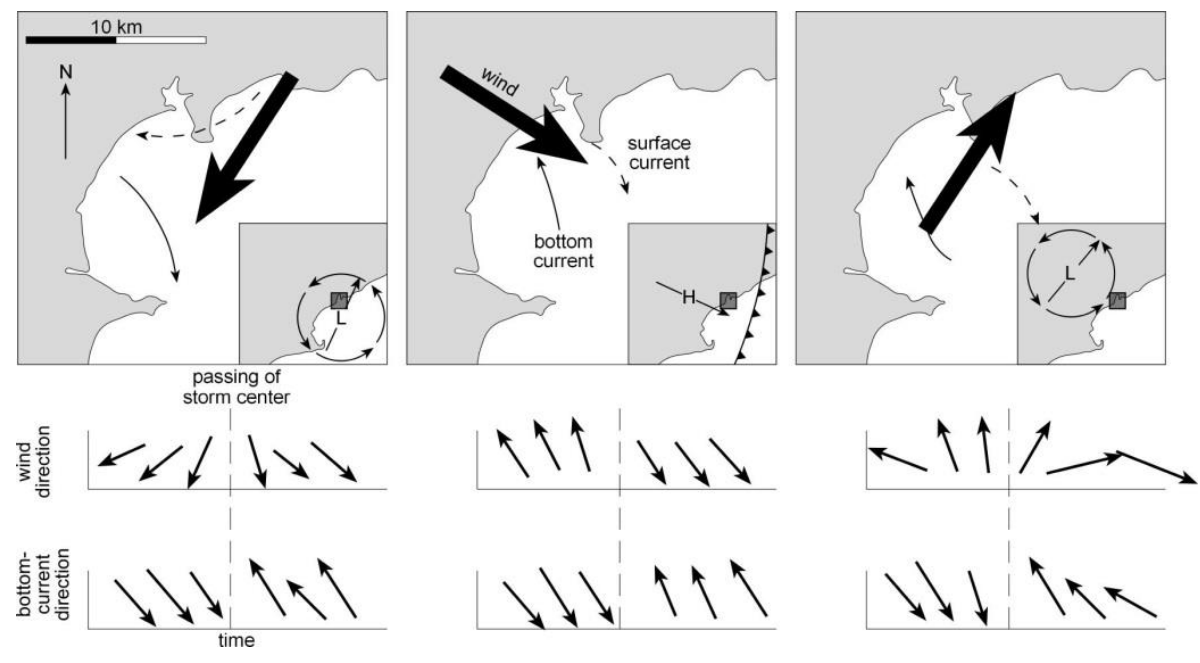

Figure 9 - Influence of different storm types on sediment transport toward and away from the Saco Bay barrier system in Maine, USA (Hill et al., 2004). From left to right, Northeast storm, Frontal passage and Southwest storm. Depending on storm characteristics, there may be either net onshore or net offshore transport. Onshore transport occurs when downwelling abates during the waning stages of storms. Dashed and solid lines represent surface- and bottom-current direction, respectively. Source: Van Heteren (2014).

\section{Barrier response to storm-generated hydrodynamic processes}

The multitude of factors and hydrodynamic processes influencing and acting on beaches and barriers results in highly variable morphological responses, both spatially and temporally. No single wind, wave or tidal parameter dominates storm-driven beach and barrier behaviour at all locations, and not even storm intensity is directly correlated to storm damage. The relative and absolute contributions of each process are determined by the local morphological, sedimentological, biological and hydrodynamic boundary conditions, and by changes in these conditions during the extreme event. Although erosion is the rule, deposition occurs as well, particularly during the waning phase of storms. Whether erosional or depositional, changes brought about by storms affect the entire coastal tract. Sediment is entrained on the shoreface, nearshore profiles are adjusted, beaches and barriers erode and accrete, inlets change and back-barrier areas deepen or shallow (cf. Forbes et al., 2004). Storm response is generally considered in a two-dimensional sense, linked to cross-shore hydrodynamics and sediment transport processes. An along-coast variability in these cross-shore processes, and hence in the morphological response, is increasingly acknowledged, however.

\subsection{Storm-Impact Scale model and the role of freeboard}

A very useful conceptual framework for considering the response of sandy beaches and barriers to storms is the Storm Impact Scale (SIS) model proposed by Sallenger (2000). The SIS model defines four storm-impact regimes, and explicitly couples hydrodynamic forcing and beach morphology by examining the relationship between the elevation of extreme water levels (Rlow and Rhigh) and relevant beach morphology $\left(D_{l o w}\right.$ and $\left.D_{h i g h}\right)$ (Figure 10). A similar framework for gravel barriers was presented by Orford et al. (2003), who proposed the term 'freeboard' to describe the difference in height between the elevation of the barrier crest and the maximum runup level. Positive freeboard occurs when the wave runup does not reach the barrier crest, whereas negative freeboard occurs when runup exceeds the barrier crest.

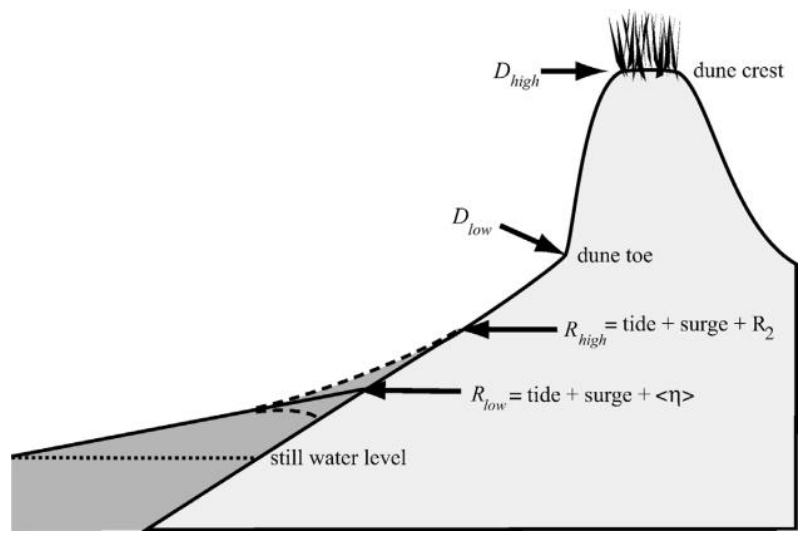

Figure 10 - Definition sketch of the Storm Impact Scale (SIS) model of Sallenger (2000), illustrating

$R_{\text {low }}, R_{\text {high }}, D_{\text {low }}$ and $D_{\text {high }}$. Parameters $R_{2}$ and $<\eta>$ represent maximum wave runup and setup, respectively (see Table 1). Source: Stockdon et al. (2007). 
In the SIS model, the mean water level during the storm, Rlow, is defined as the sum of storm surge, astronomical tide and wave setup (note that this formulation proposed by Stockdon et al. (2007) differs slightly from that of Sallenger (2000), who defined Rlow using the elevation of the seaward limit of swash, which is rather difficult to quantify). The highest elevation of the landward margin of swash, the runup limit, is denoted by Rhigh. This measure includes the combined effects of astronomical tides, storm surge and the $2 \%$ exceedance level for vertical wave runup, including both setup and swash. The elevation of the first line of defence of a beach against storm waves (i.e., beach berm or dune crest) is denoted by Dhigh, and the elevation of the toe of the dune is indicated by $D_{\text {low. }}$ When a dune is not present, Dlow is not defined.

By considering how Rhigh and Rlow vary with respect to $D_{h i g h}$ and $D_{l o w}$, four impact regimes are defined (Sallenger, 2000):

- $\quad R_{\text {high }}>D_{\text {low }}-$ Within the swash regime, wave runup is confined to the foreshore, and sand eroded during storms is generally moved offshore.

- $\quad$ Dhigh $>$ Rhigh $>$ Dlow - The collision regime comes into force when the maximum water level exceeds the base of the dune, but is not higher than the top of the dune. Here, runup collides with the dune causing erosion that may be more longlasting than foreshore erosion.

- $\quad$ Rhigh $>$ Dhigh - Overwash occurs when the maximum water level exceeds the height of the dune or the berm. Within this regime, sand is transported landward and not readily returned to the seaward side of the island.

- $\quad R_{\text {low }}>D_{\text {high }}$ - Inundation is the final and most extreme regime and occurs when the beach and dunes are completely and continually under water.

Since its introduction, the SIS model has been widely used in the USA (see http://coastal.er.usgs.gov/hurricanes/impact-scale/) and has been found to explain along-coast variability in barrier response to hurricanes very well (e.g., Stockdon et al., 2007). Coupled to hydrodynamic predictors and LiDAR-derived barrier morphology, the SIS model is also a powerful tool for predicting hurricane impacts (Stockdon et al., 2009).

In further elaborations on the various types of barrier response, a distinction is made between the short-term impact of single storms under various impact regimes and the long-term effect of multiple storms and fair-weather periods on overall barrier development.

\subsection{Swash regime}

Subaerial beach erosion, berm destruction, nearshore bar formation and offshore bar migration are well-established consequences of high-energy wave action (e.g., Komar, 1998). The response of a beach to storm-wave conditions is not simply a function of wave energy; rather, it very much depends on the degree of disequilibrium that is represented by the storm-related hydrodynamic conditions. For example, beaches that are attuned to high-energy wave conditions may be relatively insensitive to all but the most extreme storm waves (Cooper et al., 2004). Therefore, antecedent wave conditions are highly significant, and the beach response to the first storm of the season is likely to be more pronounced than changes caused by subsequent events (e.g., Coco et al., submitted). There are exceptions to this rule and Castelle et al. (2007) documented offshore migration of the outer bar during a first major storm, leaving the beach relatively unprotected and causing disproportional beach erosion during subsequent storms of less intensity. The actual beach morphology is important as well. Qi et al. (2010) convincingly demonstrated that beach-gradient change decreases with beach gradient (Figure 11) (cf. Rangel-Buitrago and Anfuso, 2011), supporting the long-held notion that flatter beach types are more stable than steep beach types (Wright and Short, 1984). A similar result was obtained by Aagaard et al (2005) who found that gently sloping shoreline salients (mega-cusps) were highly stable and displayed only minor slope adjustments through a storm period, whereas steeply sloping embayments were eroded significantly.

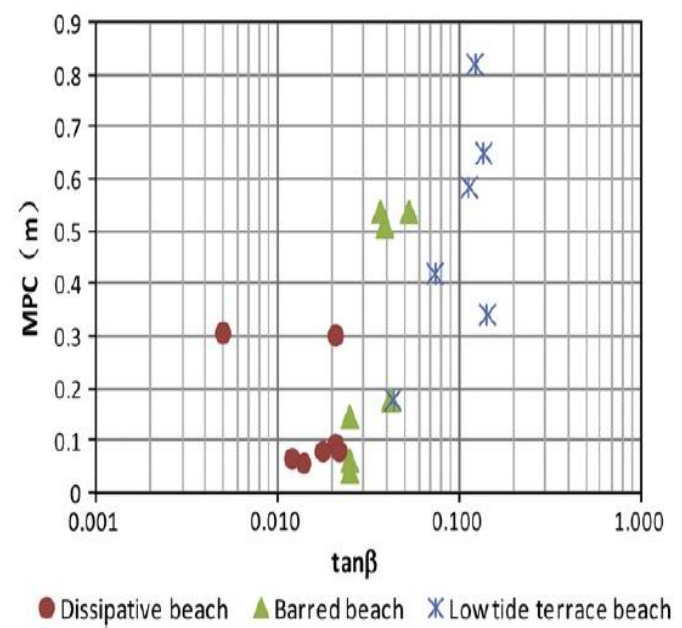

Figure 11 - Mean storm-induced profile change MPC (summation of all absolute beach-level changes over the entire active profile) as a function of the beach gradient tan $\beta$ for eight different beaches and six tropical storms in the South China Sea. Source: Qi et al. (2010). 
The behaviour of nearshore bars, characteristic of intermediate beach types (Wright and Short, 1984), under storm-wave conditions has been elucidated during the last two decades through the availability of long-term daily video monitoring data that uses breaker patterns as proxies for nearshore-bar morphology (Holman and Stanley, 2007). Bars typically move offshore during storms and onshore under calm waves (Thornton et al., 1996; Gallagher et al., 1998), in an attempt to move towards a new equilibrium position controlled by the wave breakpoint (Sallenger et al., 1985; Plant et al., 2001, 2006; Hoefel and Elgar, 2003; Splinter et al., 2011). Larger and smaller bedforms may also contribute sediment to the beach during storms. Anthony (2013) reported on the episodic welding of tidal-ridges and large subaqueous dunes to shore. It is important in this context to make a distinction between the short-term response of nearshore bars to energetic events (storms) or energetic periods (winter) and the long-term bar behaviour (years), which can be characterised by persistent onshore (Aagaard et al., 2007) or offshore (Ruessink et al., 2003) migration. Changes in the wave forcing also affect the alongshore rhythmicity of the nearshore bar morphology and it has been alleged that bars become increasingly two-dimensional during storm conditions (Short, 1978; Lippmann and Holman, 1990; Ranasinghe et al., 2004; Armaroli and Ciavola, 2010). An excellent example of this phenomenon is provided in Figure 12, which shows the straightening of a highly crescentic bar system next to a sandy beach as a result of a six-week period of highenergy wave action (Senechal et al., 2011a; Coco et al., submitted). However, Price and Ruessink (2011) demonstrated that, at least for their double-barred site on the Australian Gold Coast, increased (decreased) two-dimensionality is not necessarily related to increased (decreased) wave energy, but more likely linked to stronger (weaker) longshore currents. Rhythmic bar morphology is modified by energetic wave conditions, but can itself modulate the shoreline response through morphodynamic feedback.
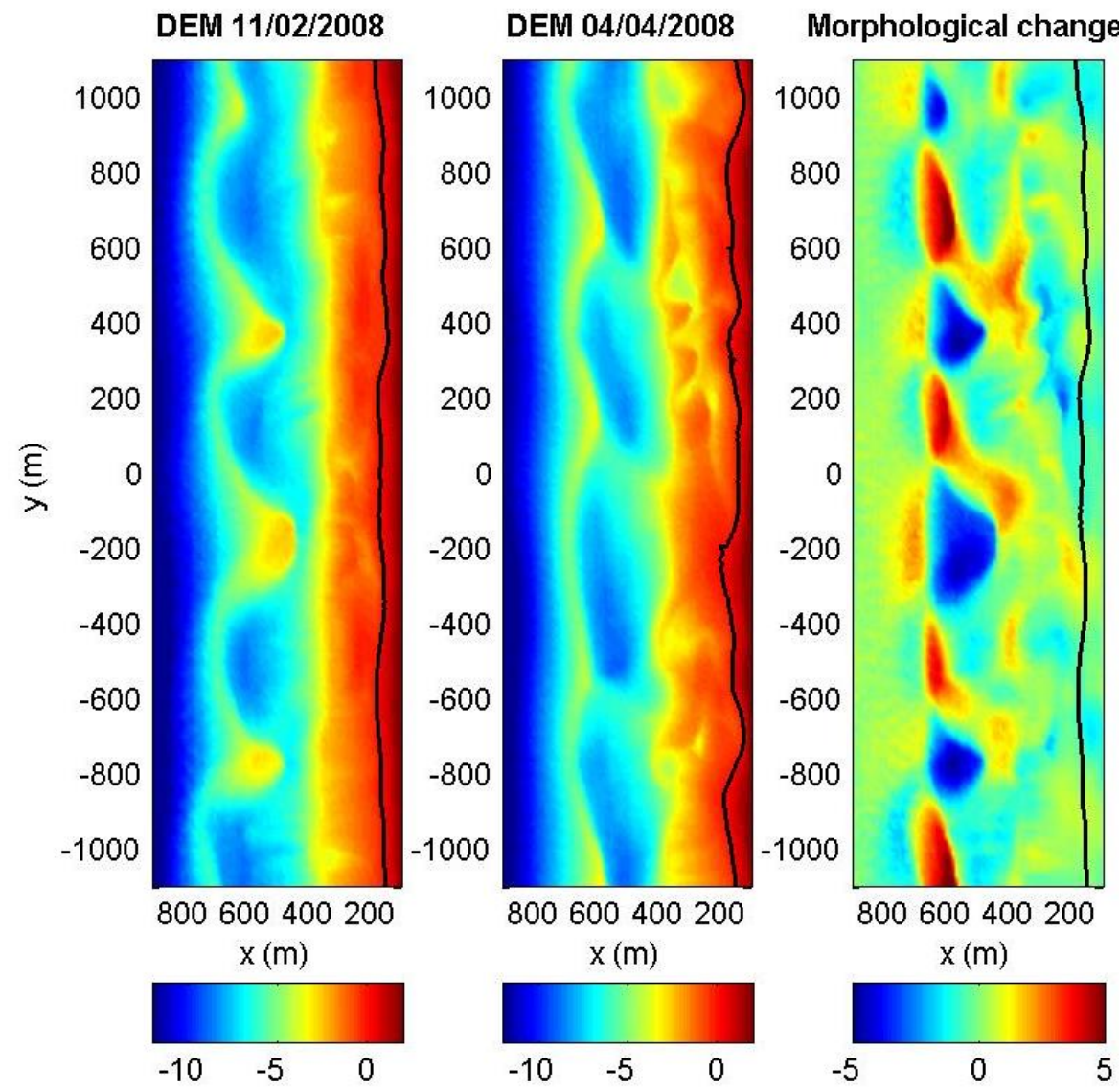

\begin{abstract}
Figure 12 - Response of the inter-and subtidal bar system of Truc Vert beach on the French Atlantic coast to a one-month period of persistently high waves $\left(\mathrm{H}_{\mathrm{s}}>3 \mathrm{~m}\right)$, including an extreme storm with maximum $\mathrm{H}_{\mathrm{s}}$ of $8.1 \mathrm{~m}$. The left two panels show the digital elevation model (DEM) for 11/02/2008 and 04/04/2008, respectively, and the right panel shows the morphological change over this period. The solid black line in the plots represents the MSL contour. During the survey period, the subtidal crescentic bar system underwent significant straightening and offshore migration, and the maximum bed-level change was $5 \mathrm{~m}$. Remarkably, the upper intertidal and subaerial beach underwent only minor morphological change and the dunes were not affected at all. This is attributed to the minimal storm surge $(<1 \mathrm{~m})$ and the extreme dissipative surf zone conditions during the height of the storm. Source: Coco et al. (submitted).
\end{abstract}

Beach-ridge construction and storm conditions have most clearly been linked in the rapidly rising and falling Caspian Sea; here, only storm surges can mobilise sufficient coarse-grained sediment to create low barriers or move and rework them in a landward direction (Kroonenberg et al., 2000). It is thought that ridges are generally the cumulative result of swell-related runup, resulting from far-away storms that never made landfall (cf. McBride et al., 2007), ultimately nourished by gradual onshore transport of 
inner-shelf sediment during storms. Once established, ridges build vertically by crest accretion in a process that increases barrier elevation, but not necessarily its volume. Crest elevation is limited by the maximum wave runup (Orford and Carter, 1982). Storm-induced foredune accretion is much less common and involves far smaller sediment volumes. It results primarily from sediment redistribution within the subaerial barrier and takes place when water levels are low enough to expose part of the beach to the wind. Such conditions are most common when surges are either low or coincident with low or neap tides, or during a storm's waning phase. On the one hand, storm winds may transport surface sediment from beach to frontal dune (Łabuz, 2005); on the other hand, scarp excavation in the backshore may liberate sediment for aeolian transport (Lindhorst et al., 2010).

\subsection{Collision regime}

Several processes and parameters contribute to beach lowering and frontal-dune scarping, the main barrier-response types in the collision regime. Beach lowering is driven by breaking waves and bed return flow as these surf zone processes temporarily replace swash during storm conditions (Masselink and Puleo, 2006). Dune scarping is governed by direct wave impact, most influential at the dune foot, and by swash runup (upper panels in Figure 13), which erodes and saturates surficial layers higher up the dune. It occurs as long as storm-related runup does not overtop and erode the dune crest. Although scarping is most common on the sea side of barriers, it also affects secondary dunes bordering long and wide open-water back-barrier areas, such as Santa Rosa Sound in Florida (Pries et al., 2008).

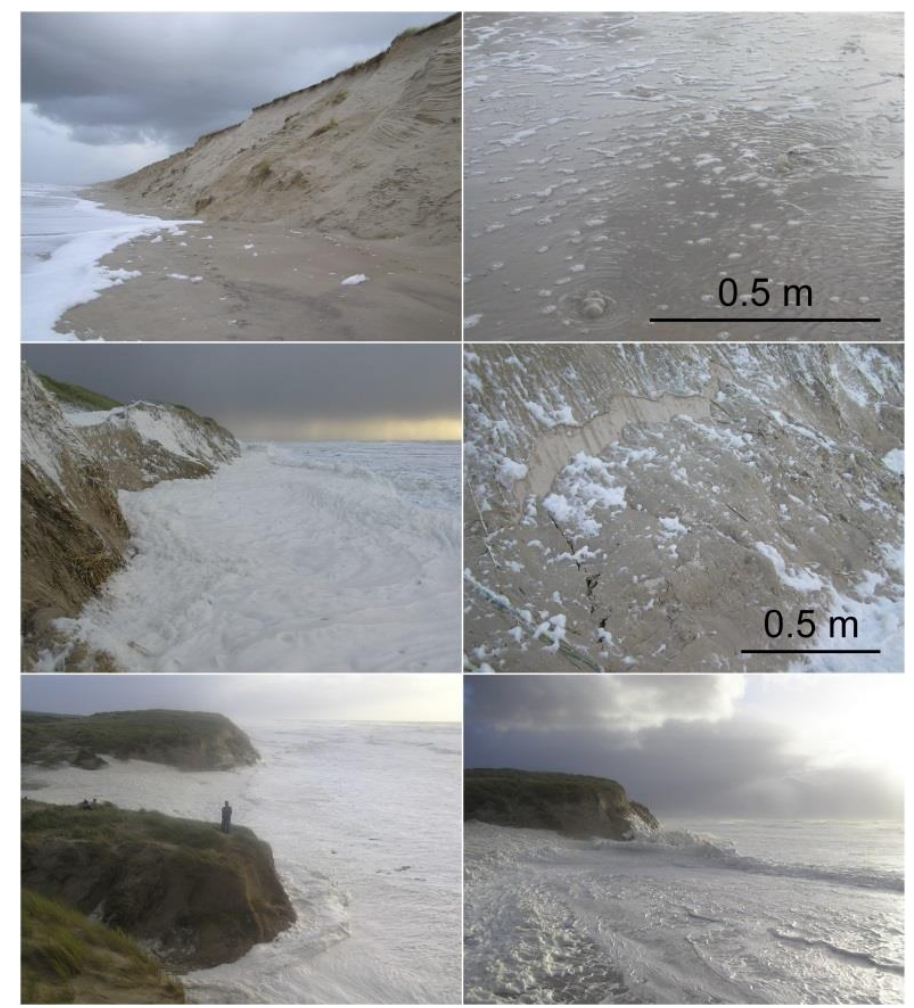

Figure 13 - Swash, collision and overwash regimes along the Dutch coast near Bergen aan Zee. The upper photos show the swash collision transition, with air escaping from unsaturated beach sand that has just become submerged as water reaches the dune foot. The middle photos illustrate how slumping takes place as a result of the saturation of basal dune sand as water reaches the dune foot in the collision regime, leaving a dry scarp surface (cf. Palmsten and Holman, 2011). The lower photos show overwash from longshore (left) and cross-shore (right) perspectives. All photos by Marcel Bakker.

In determining degree and rate of dune scarping, effects of storm-related parameters (wave height, storm-tide level, duration, wind variability) are overprinted to varying degrees by foredune profile (including height and dune-foot elevation), beach profile (width and steepness), rate of sediment supply, grain-size distribution, sediment consolidation and vegetation (Van de Graaff, 1986; 1994; Saye et al., 2005; Esteves et al., 2012). When operating in isolation, hydrodynamic drivers show a direct relationship with the extent of scarping, which also increases with steepening beach and dune profiles, diminishing sediment supply, and decreasing grain size, consolidation and vegetation density (cf. Pye and Blott, 2008). Because of feedback mechanisms and interaction between forcing factors, actual relationships are less clear. Rapid initial scarping of high foredunes, for example, may raise the backshore, thus reducing wave impact as a storm progresses (i.e., negative feedback). In governing in-situ pressure and flow velocity, wave impact is also more influential on micro- and mesotidal than on macrotidal coasts, where tidal phase is the dominant component of storm tide, rather than surge or wave height (Esteves et al., 2012).

Scarping can take place through sliding and flowing, layer separation, or notching and slumping (Nishi and Kraus, 1996). These processes occur when the resisting strength of dune sediment is exceeded by destabilising forces along failure planes. Sliding and flowing are limited to gently-sloping dune fronts. Modest wave impact and swash force steepen the foredune slope by eroding 
surficial sediment near the dune base. In layer separation, cracks developing in steep, destabilised dune faces gradually separate an up to $0.5-\mathrm{m}$-thick layer from the dune core. This layer may either collapse or tilt forward. Notching and slumping affect steep dune faces held together by roots, soil moisture or interstitial cementation (cf. Carter et al., 1990). As wave-cut notches expand, the overlying sand slumps down in blocks that commonly remain partly intact. Sand thus removed from the continuous foredunes is commonly stored temporarily on the beach and in the nearshore zone.

Swash water infiltrating the dune face horizontally, either by suction through capillary action or as a result of direct impact, is a strong and rapid destabiliser (Palmsten and Holman, 2011). As it saturates the sand, the weight of the water increases the overburden and entire blocks of sediment held together by moisture-related cohesion slump down. When storm tides are high enough to both undercut and permeate dune sand, infiltration-governed destabilisation may also take place where steep dune fronts limit swash (Pye and Blott, 2008) (middle panels in Figure 13). The minimum storm-tide level required for this process depends on the seasonally changing elevation of the backshore and the dune foot (Esteves et al., 2012).

\subsection{Overwash regime}

The same processes and parameters that govern barrier behaviour in the collision regime are also strongly influential in the overwash regime, with a prominent role for beach-ridge and foredune profiles. Longshore variability in these profiles is an important element in determining the freeboard or overwash potential, which are defined as the difference between wave runup and crest elevation (Matias et al., 2012). The transition between the collision and overwash regimes is marked by overtopping. Where maximum water levels exceed the lowest crestal sections by only a few decimetres and where crestal width is large, overtopping is limited in extent and frequency. At these vulnerable sites, runup-governed accumulation overwash raises the barrier crest, steepens the upper beach (Donnelly, 2007; Matias et al., 2012), and at least temporarily reduces the likelihood of further overtopping. Dissipative forces, including infiltration, cause the deposition of locally derived sediment (eroded from dune front, beach and nearshore) on the crest or directly behind it. In coarse-grained barriers, sediment may even be deposited in an incipient or reactivated throat, creating a temporary plug before a further rise in water level allows larger waves to erode it (Carter and Orford, 1981). Sediment deposited on the backside of higher ridges may be redistributed by avalanching, particularly where backbarrier water levels are high (Matias et al., 2012).

Temporary accumulation overwash is most likely during short-lived, moderate storms. Long and severe storms have more time and energy to narrow and lower frontal dunes, and are thus more likely to result in full overwash conditions (Donnelly et al., 2006). Discrete overwash is a moderate-magnitude event set into motion when runup of most waves exceeds the barrier crest by at least a few decimetres, resulting in local overflow and a commensurate halt to dune scarping. Once the frequency of overtopping increases, incipient barrier-crest erosion and breaching trigger a rapid intensification of the overwash process and an overall flattening of the beach. These processes are more strongly correlated to storm duration and surge level than to wave height (Donnelly, 2007). When enough storm water exceeds the lowest areas of a beach or foredune ridge backed by a lower interdune or back-barrier area, it funnels through these commonly narrow gaps (lower panels in Figure 13). Here, velocities exceed $2 \mathrm{~m} \mathrm{~s}^{-1}$ (Donnelly et al., 2006), a function of the steep water gradient between the sea and the flooded lows together with the strong flow constriction (e.g., Suter et al., 1982). Swash reflection from the dunes next to a gap also contributes to accelerated flow, and to turbulence that results in further deepening of the throat (Carter and Orford, 1981). Friction and percolation on the backside of throats are instrumental in the deposition of washover fans by sediment-laden water that is no longer constrained. Most of the overwashed sediment remains on the barrier, which slows the water before it reaches too far into the back-barrier area. Barrier width and vegetation-related friction play a role (Donnelly et al., 2006).

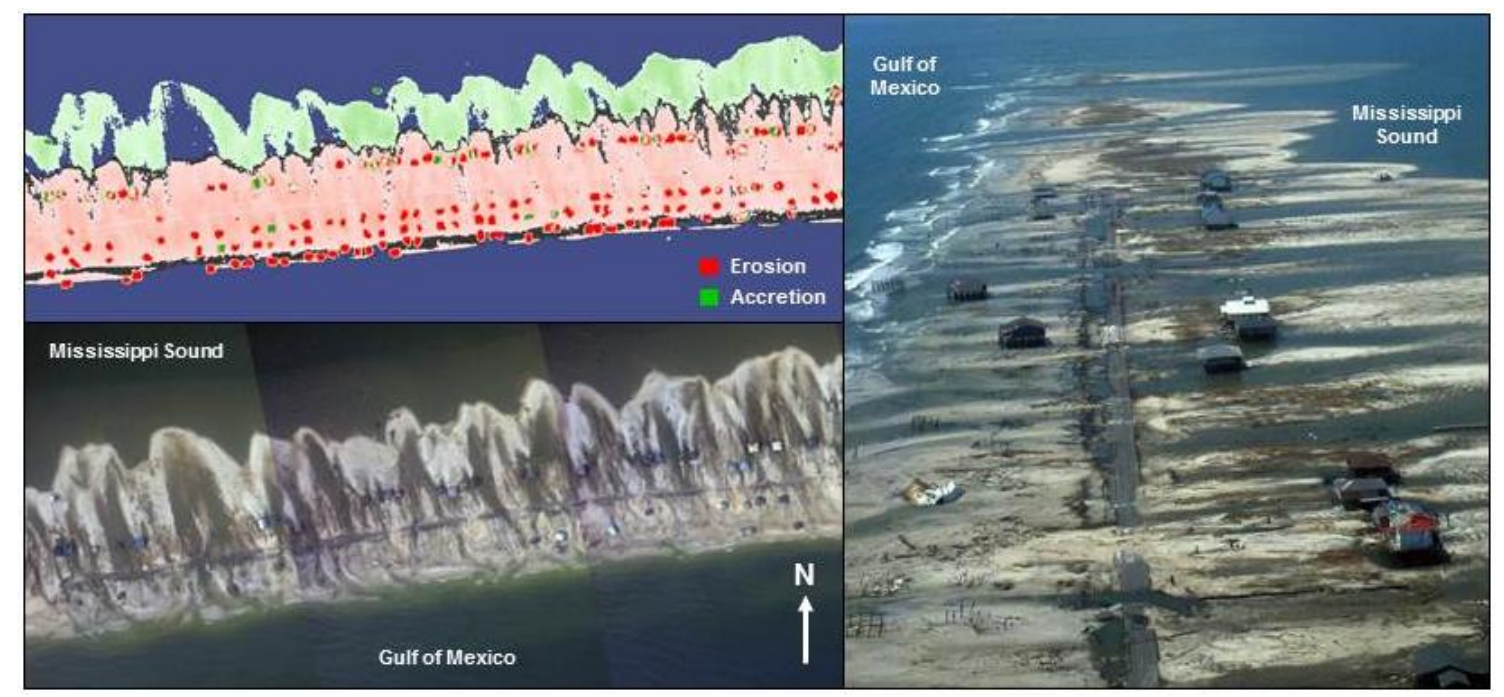

Figure 14 -Response of Dauphin Island, Alabama, in the Gulf of Mexico to Hurricane Katrina in 2005. Upper-left panel shows post-storm difference grid obtained using LiDAR representing the period September 2004 to September 2005 and lower-left panel shows vertical photograph of the same region. Right panel shows oblique photograph of the west end of the Dauphin Island after Hurricane Katrina. Note the erosion of the front of the beach and the crest 
During the initial storm stages, the constricted, rapidly flowing water may not cause much erosion outside overwash throats. As the water level continues to rise, however, and cross-sectional volumes thus increase, breaches are commonly widened (e.g., Houser et al., 2008; Pries et al., 2008). Adjacent breaches may create fans that merge to form washover terraces (Figure 14). Deceleration of overwash currents, mostly during the waning phase of a storm, results in loss of transporting capacity and associated sand deposition in the throat (Fisher et al., 1974). In general, minor lows are more likely to be deepened, whereas more prominent lows may grow sideways rather than vertically, which may reduce the overall variability of dune-crest elevation (Houser, 2013). 


\subsection{Inundation regime}

Sluicing or inundation overwash, the main process associated with the inundation regime, is a high-magnitude event initiated when mean water level exceeds the barrier crest over extensive distances, either because of extreme water levels or because the impacted beach ridges or barriers are low. Full barrier inundation is more common for sandy barriers than for coarse-grained beach ridges and barriers (Orford et al., 2003). When the storm surge is sufficiently high to overtop the entire barrier continuously, strong currents may erode most of the sand and transport it so far beyond the subaerial barrier that it is no longer part of the barrier lithosome (Sallenger et al., 2007). As the sea and the back-barrier area become fully coupled, the gradient between the two determines the flow conditions and thus the transported sediment volumes (Donnelly et al., 2006).

Storm-pass and inlet formation result when gaps deepened and widened by overwash fully connect to open-water back-barrier areas, most commonly where barriers are narrow and low. Storm passes become inactive as soon as storm waters recede, whereas inlets keep exchanging water at least for some time during subsequent fair-weather ebb and flood. Where storms have shorenormal and right-oblique tracks in the northern hemisphere, storm passes are initiated from the seaward side. Storms with leftoblique tracks are more likely to initiate storm passes from the back-barrier side (Penland and Suter, 1984). Storm passes or inlets formed during ebb flow are triggered by elevated water levels in back-barrier areas, a mechanism already noticed by Hite (1924) almost a century ago, with drainage forced by offshore winds. Once formed, inlets may be widened by strengthening tidal currents (Orford et al., 2003), generated in part by tidal-prism increases related to back-barrier widening and deepening (Fritz et al., 2007). Barrier erosion by storm-generated temporary and permanent inlets affects more than half of the US East Coast (Zhang et al., 2002). Shinnecock Inlet on Long Island, formed during the 1938 Hurricane, is an example of a permanent inlet that evolved rapidly from an initially small breach (cf. Buynevich and Donnelly, 2006). Nearby, the same storm produced ten other breaches along a 50-km-long stretch of microtidal coastline, but none of those became permanent (Canizares and Irish, 2008). Even during storms, there is a limit to the number of simultaneously active inlets. In facilitating the drainage of back-barrier surge water during the waning stage of storms, the presence of permanent inlets is known to reduce the likelihood of storm-pass formation by ebb flow (Leatherman, 1979). Where new inlets do form, existing ones are commonly closed by longshore and onshore sediment transport once tidal prism is reduced to fair-weather values (McBride and Robinson, 2003). Closed inlets are likely to be reactivated during subsequent storms, however, because their scars are commonly marked by vulnerable foredune gaps (Suter et al., 1982).

The ultimate and most severe morphological consequence of storms is complete barrier disintegration. It can take place from the seaward as well as the landward side of low-resilience barriers (e.g., Grzegorzewski et al., 2011), and has recently been documented at the Chandeleur Islands in Louisiana. During Hurricane Katrina, the islands became fully submerged, and some $85 \%$ of the sand stripped from their beaches and dunes was deposited where it could no longer nourish the islands as part of post-storm recovery (Sallenger et al., 2007). Thus, an originally 40-km-long sandy island chain was transformed into a discontinuous series of muddy marsh islets. On the northern end of Assateague Island, disintegration is prevented only by frequent nourishment with sand extracted from the adjacent inlet and associated tidal deltas (Gutierrez et al., 2009). Upon storm-triggered disintegration, a barrier may re-form farther landward during subsequent fair-weather periods, as part of a process called overstepping (Forbes et al., 1991). Such a new barrier can only be formed when a suitable anchor point and sufficient local sediment are available

\subsection{Long-term response}

In the long term, storms play an integral part in barrier behaviour. Rollover, barrier narrowing and disintegration are common and presently observed changes that are driven primarily by storm impact. The main mechanisms driving rollover are overwash and inlet formation (Leatherman, 1985; Lentz et al., 2013), which both helping to maintain barrier width and volume (e.g., Godfrey and Godfrey, 1973). At Fire Island, New York, overwash vulnerability and profile retreat by rollover are strongly linked, with aeolian processes also playing an important role in landward island migration (Lentz et al., 2013). Long-term rates of barrier retrogradation are governed in part by overwash frequency and washover extent (e.g., Dolan and Godfrey, 1973). Barrier narrowing, which takes place in the absence of rollover, is a result of extended periods during which collision-regime processes are dominant. Narrowed barriers are vulnerable to disintegration once overwash and inundation become increasingly frequent.

\section{6 .Spatial and temporal variability and patterns}

Because of differences in short- and long-term influences and hydrodynamic drivers, barrier response is marked by high spatial variability. Adjacent gravel barriers in different modes of activity are a most extreme example (Orford et al., 2002). Part of this variability appears to be random, reflecting effects from a multitude of controlling factors that may or may not be superimposed on a general trend. By necessity, differential behaviour without a clear pattern is usually explained by ad hoc reasoning that may have little generic value. Pries et al. (2008), for example, explained an unusual, inverse relationship between erosion of Santa Rosa Island in Florida on the one hand and distance from hurricane landfall on the other hand by hypothesising an increase in back-barrier storm-surge magnitude away from the landfall location, caused by a narrowing sound. Corroboration of this proposed site-specific mechanism by evidence from elsewhere will be difficult.

When single variables dominate storm-related barrier behaviour, it is more likely for recognizable patterns to develop, although they may differ strongly between erosion indicators. Some behavioural patterns are simple. Three-dimensional surf zone morphology, for example, significantly affects wave-breaking processes and nearshore current patterns. Thornton et al. (2007) 
demonstrated that dune erosion can preferentially occur opposite rip current embayments, thus creating regularly spaced erosion hot spots. For barriers in the northern hemisphere, Savage (1985) noted the prevalence of net erosion on the right of the landfall location, where onshore winds are strongest, and the prevalence of net accretion to its left, where offshore winds dominate. Longshore rhythmicity in overwash positioning varies in scale from tens of meters on gravel barriers (Orford and Carter, 1982) to many kilometers on sand barriers (Dolan and Hayden, 1981). Beach and nearshore morphology and their influence on runup height are clearly of influence (Orford et al., 2002), as shown by measurements of the Coastal Lidar and Radar Imaging System CLARIS (Brodie and McNinch, 2009; Figure 8). Explanations for these rhythmicities include the presence of beach cusps (Orford and Carter, 1984), filtering of wave energy by sand bars (Brodie et al., 2012) and entrapment of standing waves between promontories (Dolan and Hayden, 1981). For a cuspate barrier along the Gulf of St. Lawrence, rhythmic erosional hotspots spaced 100-500 m apart were linked to gaps in the longshore-bar system, and larger-scale variability was related to relaxation time in response to storm events (Xhardé et al., 2011). At Santa Rosa Island in Florida, multiple periodicities in coastal response, at scales of about 750, 1450 and $4550 \mathrm{~m}$, are reflected in dune height and width, supposedly linked to transverse ridges on the inner shelf, cuspate promontories on the landward barrier side, and cross-shore washover extent (Houser et al., 2008).

Positive and negative spatial gradients in storm-related longshore sediment-transport rates cause barrier erosion and accretion, respectively, and where such gradients are significant, so will be the change induced by this process. In extreme cases, cannibalization will occur, with entire barrier sections disintegrating at the cost of others in response either to temporary, stormdriven littoral drift reversals (Xhardé et al., 2011), or to positive littoral drift gradients. The adjustment of the beach planform as a result of longshore transport gradients is referred to as 'beach rotation'. Beach rotation resulting from changes in the directional wave climate has been well documented over decadal and seasonal time scales (e.g., Masselink and Pattiaratchi, 2001; Harley et al., 2011; Thomas et al., 2011; Turki et al., 2013), but can also take place in response to a series of storms. Alegria-Arzaburu and Masselink (2010), for example, found opposing longshore energy fluxes and differing beach response depending on storm-wave direction for a 5-km-long macrotidal gravel beach on the southwest coast of England. They attributed this pattern to alongshore gradients in the longshore sediment flux (Figure 15). The northern end of the beach widened by c. $30 \mathrm{~m}$ and the central part of the beach receded by c. $40 \mathrm{~m}$ over a relatively brief period (a few months), owing to a higher frequency of southerly storms and/or a lower frequency of easterly storms over this period. The importance of both cross-shore and longshore sediment-transport processes in controlling storm response was further highlighted by Galal and Takewaka (2011), who used LiDAR data to study the response of a 53-km-long section of beach on the Japanese main island Honshu to high waves and storm surge. Using SWAN wave modelling to estimate wave conditions along the coast during an extreme storm, they found that the distribution of energy flux explains the observed erosion pattern quite well: alongshore variability in cross-shore energy flux was responsible for the large-scale variability in erosion, whereas gradients in the alongshore energy fluxes caused shorter-scale variability. Finally, Archetti and Romagloni (2011) monitored the morphological response of artificial embayments along the northeast coast of Italy (Lido di Dante) to NE Bora and SE Sirocco storm waves. They demonstrated that northeast and southeast storms produce shoreline rotation in anticlockwise and clockwise directions, respectively, reflecting direction reversals of longshore currents in the nearshore.

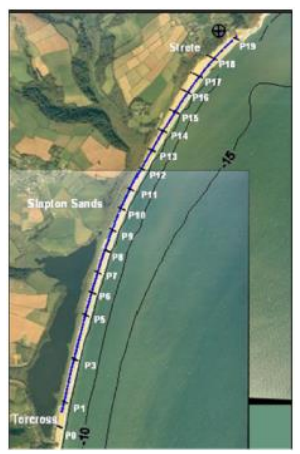

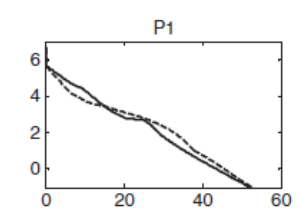

$\mathrm{P} 12$
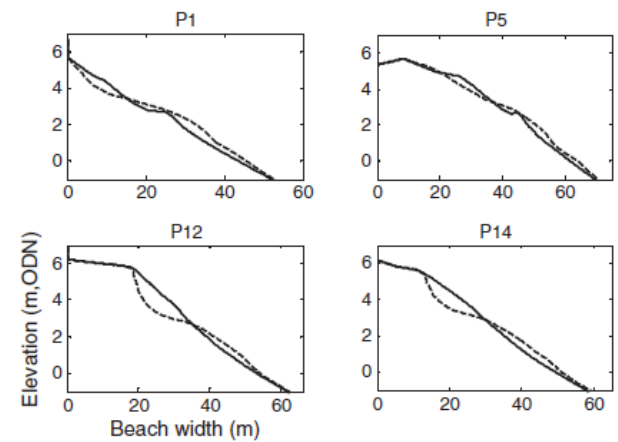

P14
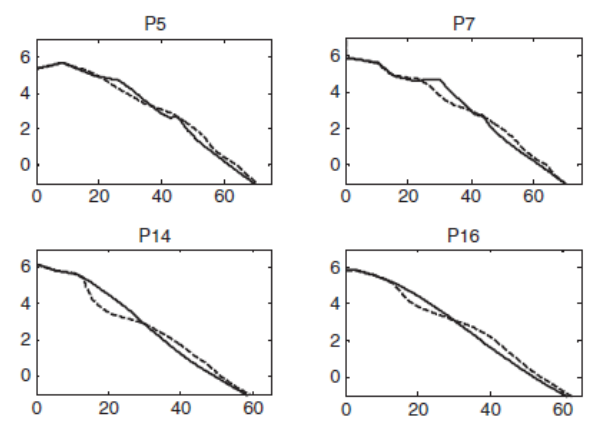

P16
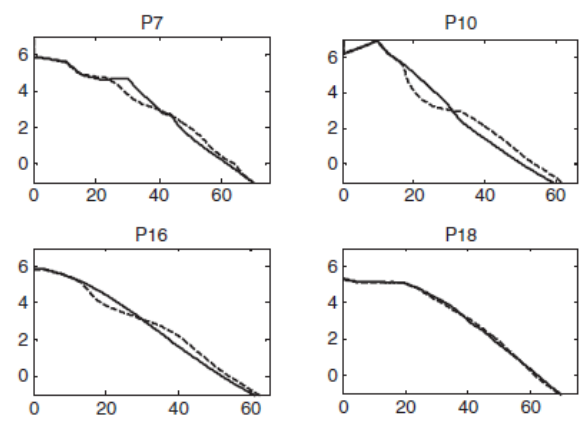

$\mathrm{P} 18$

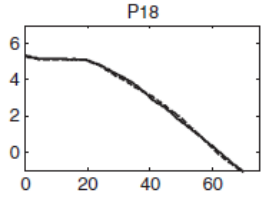

Figure 15 - Alongshore variation in morphological response of a 5-km-long gravel beach in the southwest of England to an easterly storm with peak $H_{s}$ of $4 \mathrm{~m}$, partly attributed to alongshore gradients in the longshore sediment flux. Source: Alegria-Arzaburu and Masselink (2010). Base map from GoogleEarth.

When quantifying spatial patterns, it is important to consider information from multiple indicators of barrier behaviour and to be aware of measurement error and limitations. A single indicator may show a pattern that can easily be attributed to one dominant parameter, but analysis of secondary indicators and consideration of overall uncertainty may shed additional light on storm-related erosional and depositional processes. Analysing four consecutive hurricanes battering Florida in 2004, Sallenger et al. (2006) noted that observed net volume changes caused by Hurricane Ivan showed a simple reduction in coastal erosion with increasing distance from landfall, as expected when local factors are of minor importance. Comparing longshore patterns of the positive and negative volume changes, they noted that beach and dune erosion were in fact higher 80-100 km from landfall than anywhere else along the coast. Far from landfall, relatively low barriers were subject to massive overwash: erosion of their ocean sides was compensated by deposition on their back-barrier sides (Figure 16). Closer to landfall, frontal dunes were higher and eroded sediment was likely stored subtidally, in the nearshore and on the shoreface, rather than transported across the barrier. As these subtidal environments had not been monitored, the originally observed trend in net volume change was shown to be flawed. 

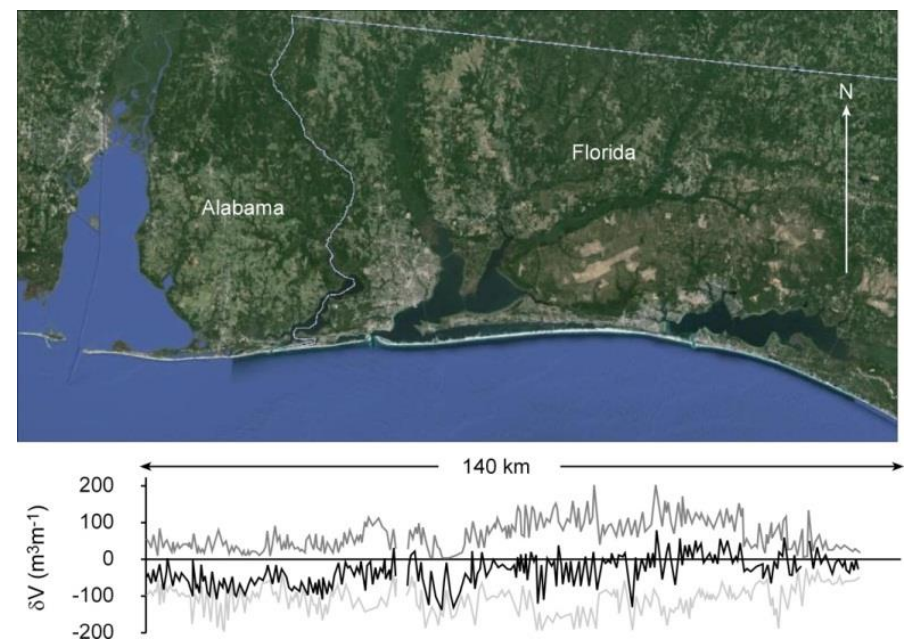

Figure 16 - Volume change $\delta \mathrm{V}$ calculated from LiDAR data acquired from a section of barrier coast in Alabama and northwest Florida, impacted by Hurricane Ivan and located to the right of its landfall location. Negative (positive) values represent inter-and supratidal sediment losses (gains) within 50$m$-wide cross-shore sections of coast (grey lines). The net change in sediment volume (gain minus loss) is represented by the solid black line. Volume loss and gain typically go together in the same section, for example where sand is eroded from the beach and transported landward of the berm or dune where it is deposited in washovers. Source: Sallenger et al. (2006). Base map from GoogleEarth.

Like spatial variability, temporal variability concerns individual storms, storm-to-storm differences, and cumulative effects of multiple storms and fair-weather periods. During individual storms, barrier response through time is a function of storm phase and of changes caused by the storm so far. Common temporal patterns are a shift from downwelling to upwelling conditions, and reduced foredune scarping as eroded sediment forms a protective buffer on the backshore. Between-storm differences may be more random. The observed rhythmicity in foredune scarping at Wissant Bay in northwestern France is explained by different combinations of wave height, spring tide and storm surge (Sedrati and Anthony, 2007). Along the coast of Fire Island, erosion and accretion cells migrate seasonally (Lentz et al., 2013) and storm-beach hotspots reverse as a function of storm type (List et al., 2006). A clear example of temporal variability in barrier response comes from the Gulf of Mexico. Between 1886 and 1993, 28 hurricanes affected Santa Rosa Island in Florida, but most associated storm tides were insufficiently high to breach its dunes. No breaching occurred from 1927 to 1975 . From 1995 onward, however, direct or near-direct hits by strong hurricanes have created multiple breaches that have not had the time to heal since, with severe damage to the dunes as a result (Pries et al., 2008).

When looking at barrier response over a period of decades, observed behaviour must be considered in light of the monitoring time span (Lentz et al., 2013). Changes over 10- and 30-year periods at Fire Island, New York, are almost mirror images (Figure 17), reflecting a recent change from recovery-dominated to storm-dominated conditions. The fact that the most substantial landward shoreline movement took place where the greatest seaward advance had occurred earlier, illuminates an interesting relationship between storm impact, which tends to disrupt shoreline continuity, and recovery, which causes shorelines to regain their continuous longshore profile. Although temporal coverage is insufficient to identify the specific effects of stormy and less stormy periods, similar patterns for shorter quiescent (1998-2002) and stormy (2002-2008) periods (Lentz and Hapke, 2011) corroborate this relationship. Comparison of different barrier-response indicators shows a direct, but spatially variable long-term correlation between dune-crest position and shoreline change, and between beach width and subaerial barrier-volume change. Overwash potential and dune-crest position and elevation are inversely correlated (Lentz et al., 2013).

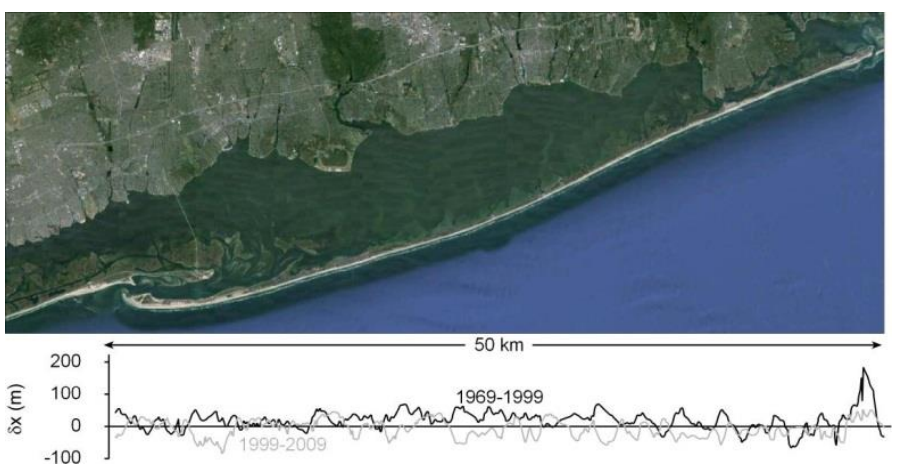

Figure 17 - Alongshore net shoreline movement at Fire Island, New York, for the 30-year period 1969-1999 and the 10-year period 1999-2009. Positive values denote accretion. The mirrored pattern suggests that, given enough time, areas disrupted the most by storms are also marked by the strongest recovery. Source: Lentz et al. (2013). Base map from GoogleEarth. 


\section{Thresholds and feedback mechanisms}

Temporal variability in barrier response to successive individual storms is often a function of exceeded thresholds and triggered feedback mechanisms, resulting in non-linear behaviour. Along the Gulf of Lions in France, moderate storms cause rapid offshore migration of nearshore bars and deposition of large sand volumes on the beach, whereas extreme storms overtop and breach the barriers, eroding or destroying the dunes (Gervais et al., 2012). Shingle ridges fail suddenly when increasing negative freeboard and strengthening waves create a critical state in which the crest is initially overtopped and subsequently eroded down (Bradbury and Powell, 1993). It commonly results from a period of negative feedback in which storm-related crest accumulation reduces the likelihood of overwash in the short term, but decreasing crest width and a steepening profile render a ridge more vulnerable in the long term (Orford et al., 2003). The sensitivity of coarse-grained barriers to negative freeboard was quantified in BARDEX experiments by Matias et al. (2012), who observed that once overwash started and crestal lowering was initiated, positive feedback resulted in further lowering and ultimate barrier destruction under constant wave characteristics and water level. In both sandy and gravelly barriers, rapid rollover occurs after the subaerial zone has narrowed to some critical cross-shore width, as observed on Assateague Island, Maryland (Leatherman, 1979). Even initially high and resilient foredunes may become subject to crest lowering and inundation overwash, either when they are thinned by long-duration storms or when they are pervasively overtopped by runup from the most extreme storms (Pries et al., 2008). When time for recovery is too short, reinforcement of the resulting gaps by overwash activity during successive storms is common (Houser, 2013). Eco-morphodynamic processes play an essential role in this feedback mechanism. Dune-building grasses provide resistance to erosion and accelerate recovery following overwash events. Renewed overwash before the re-establishment of fully vegetated dunes promotes the preferential survival of overwash-adapted 'maintainer' species like cordgrass. By helping to maintain low and flat areas, they increase the likelihood of renewed overwash, potentially initiating large-scale shifts from erosion-resilient to overwash-prone barrier morphologies (Godfrey et al., 1979; Wolner et al., 2013).

The counterforces to barrier breakdown are inertia, related to resistance to movement, and volume-related resilience, which is the ability to absorb and recover from storm impact. Inertia is most significant in gravel-dominated barriers, where the resistance of coarse clasts to sediment-transport slows overall barrier response to such a degree that extreme storms are commonly past their peaks before their full potential impacts can be accommodated (Orford et al., 2003). Inertia is also observed in sandy environments, where larger and deeper-water bedforms take much longer to adjust to storm-related changes in conditions than smaller bedforms nearshore (cf. Stive and De Vriend, 1995). While small-scale bedforms and bars on the inner shoreface may be subject to short-term readjustment to varying morphodynamic forcing, the scale of the large dunes (sand waves) on the lower shoreface and inner shelf is such that they are likely to integrate adjustments over long timescales.

Resilience is partly a function of barrier-lithosome volume, which determines the amount of sediment that needs to be eroded before a critical state is reached, and thus provides a buffering effect. It changes over time and includes an element of post-storm recovery through constructional feedback. Neither crest height nor barrier width is an effective vulnerability predictor; parameters based on shore-perpendicular cross-sectional area, such as erosion resistance (Judge et al., 2003) or barrier inertia (Bradbury, 1998; Bradbury et al., 2005) are more successful. Clearly, the combined effects of height and cross-shore volume determine barrier resilience (Figure 18). A useful way to visualise the changing vulnerability of barriers is the 'resilience trajectory'. It shows how changes in crest elevation and movement take place on various time scales, from weeks to years or longer, and under varying conditions (Orford and Anthony, 2011).

Resilience must be considered within the context of overall individual storm impact (upper panel of Figure 18). The pre-storm state of a barrier determines its initial resilience (in green) to an impending storm. Upon impact, the storm raises the water level and moves the shoreline landward, changing the threshold conditions (the relative height and width of the barrier) even before erosion commences. Active barrier lowering and narrowing during the storm move the resilience from its pre- to post-storm state, even closer to the storm threshold. For high and narrow barriers, the most likely cause of irreparable barrier destruction is narrowing, as lowering with minor volume loss may still leave enough positive freeboard. For low and wide barriers, a more likely cause of irreparable barrier destruction is inundation during passive threshold change associated with storm-tide conditions.

The storm-impact regimes defined by Sallenger (2000) result in different resilience trajectories that may jointly determine barrier response to a single storm with its waxing and waning phases (lower panel of Figure 18). In the swash regime, crest accretion and barrier narrowing are common processes, but bar welding may widen barriers. In the collision regime, barriers and especially their foredunes typically lose more width than height. In the overwash regime, height rather than width reductions are predominant, particularly if sediment eroded from beach ridges or frontal dunes is deposited on the land side of barriers. In the inundation regime, large decreases in height as well as width are likely, potentially moving a barrier into the destruction space. 


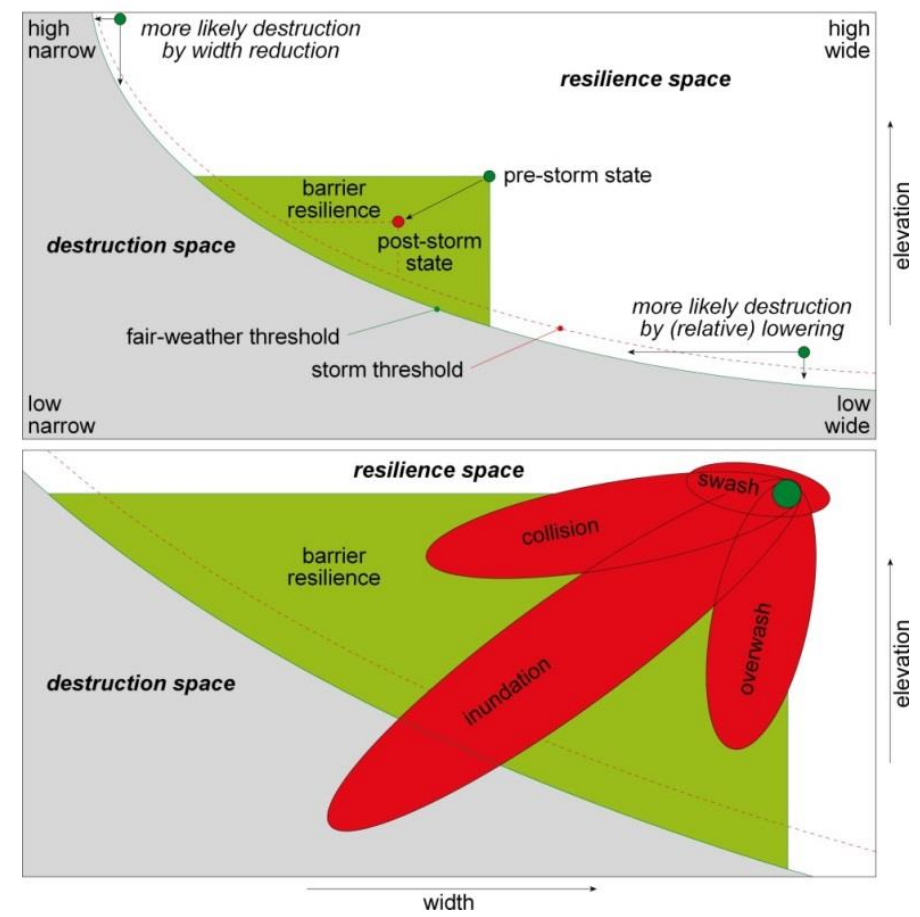

Figure 18 - Concept of resilience and destruction space as a function of barrier width and elevation, which jointly determine its volume. A full explanation is provided in the main text.

Even highly resilient and voluminous regressive barriers may reach a critical state after prolonged relative sea-level rise. Initially wide and broad barriers may prevent overwash and breaching on their sea sides, exacerbating dune scarping. On their back-barrier sides, a long-term lack of newly supplied sediment will ultimately result in permanent back-side erosion. Persistent narrowing and lowering will make overwash and breaching increasingly likely. A single storm may result in state transitioning, triggering barrier retrogradation as observed in its initial stages on Bogue Banks in North Carolina (Timmons et al., 2010).

\section{Synthesis and conclusion}

The direct impact of individual storms on barriers is strongly influenced by storm track and intensity, tidal phase and amplitude, cross-shore and longshore morphology of the coastal tract, sediment supply, barrier volumes, sediment type, and vegetation. Together, these factors govern the magnitude and variability of storm-related hydrodynamic processes and parameters, and determine the pre-storm state on which these hydrodynamic drivers act (Figure 19). Maximum storm runup and barrier morphology are the key determinants of storm impact, as conceptualised in the Storm Impact Scale model developed by Sallenger (2000). On the erosion side, the swash regime drives bar and berm flattening, the collision regime is marked by dune scarping and beach lowering, the overwash regime leads to dune scouring and channel incision, and the inundation regime may result in barrier destruction. On the deposition side, storm berms and beach ridges may form and accrete in the swash and collision regimes, localised vertical beach and barrier accretion are associated with the collision and overwash regimes, and washover deposition takes place in the overwash and inundation regimes. 


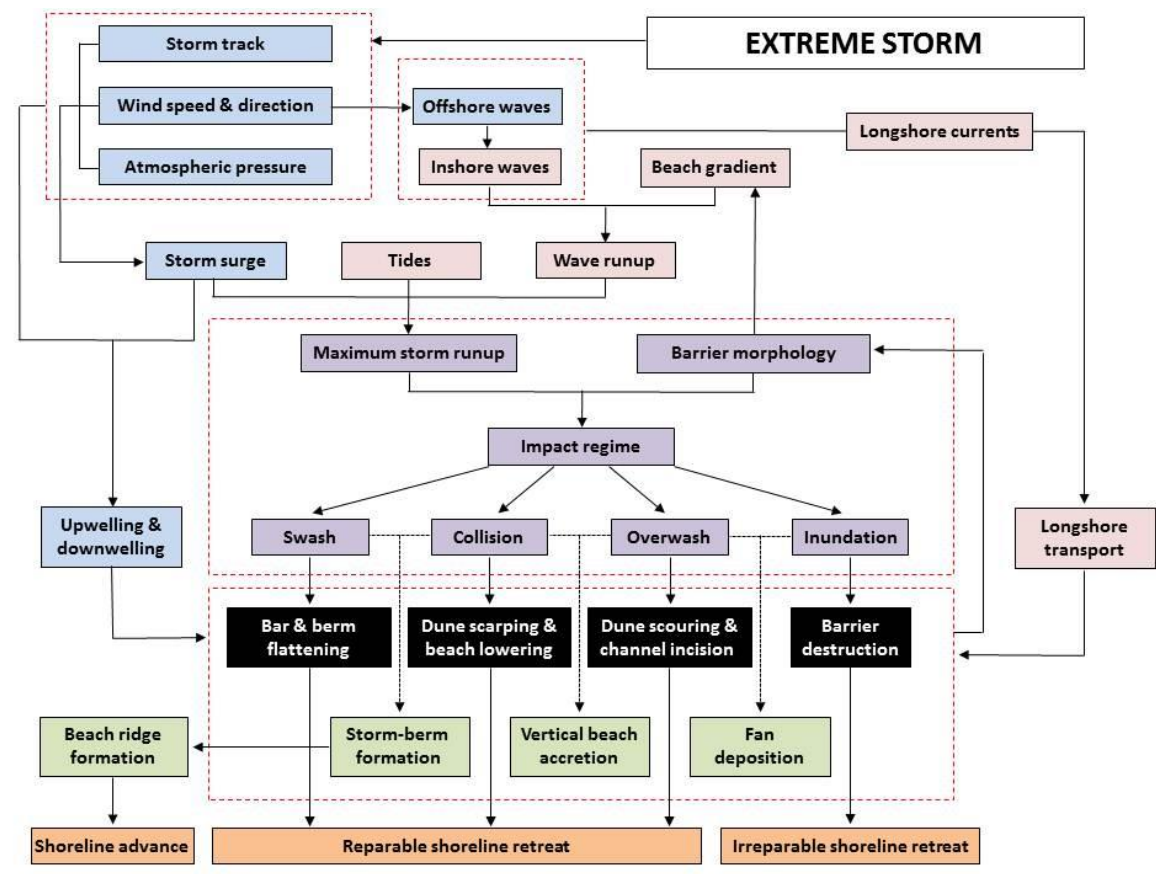

Figure 19 - Synthesis of the response of wave-dominated and mixed-energy barriers to storms. Blue boxes: storm characteristics; purple boxes: Storm Impact Scale model; pink boxes: local factors; black boxes: erosive response; green boxes: accretionary response; orange boxes: long-term trends in coastal evolution.

There is an increasing awareness, however, that barrier response to individual storms is not merely the change from pre- to poststorm state as governed by overall coastal setting and hydrodynamic processes. The direct response should always be considered in light of preconditioning, which defines the pre-storm state of the beach and barrier systems as created by previous fair-weather periods and storm events (antecedent conditions), and of post-storm after-effects and recovery (Figure 20).

The pre-storm state, as determined by short- and long-term preconditioning, can be characterised in terms of vulnerability and resilience. Both storms and fair-weather processes play a role and, although the strongest effects are to be expected from recent extreme events, even millennial-scale changes still have an effect. Partly healed breaches may be reactivated (Wright et al., 1979; Morton, 2002) and low post-storm dunes covered by burial-tolerant vegetation are easily overwashed (Houser, 2009). Welldeveloped foredunes and gravel barriers matured during extended fair-weather periods offer resilience to overwash and breaching. In the literature, much of the focus is on earlier storms lowering coastal resilience, commonly used to explain seemingly disproportional impacts of moderate storms. The influence of pre-storm fair-weather preconditioning was discussed by Regnauld and Louboutin (2002) for the sediment-starved coast of Brittany, France. They linked net accumulation on small barriers during onshore storms to long preceding periods of offshore winds producing calm seas and thus facilitating sedimentation in the nearshore and shoreface zones. Storms following fair-weather periods marked by onshore winds resulted in coastal erosion because they struck a depleted underwater environment. On a more generic level, background energy conditions have a direct bearing on barrier susceptibility, with low-energy coasts being more vulnerable than their high-energy counterparts. 


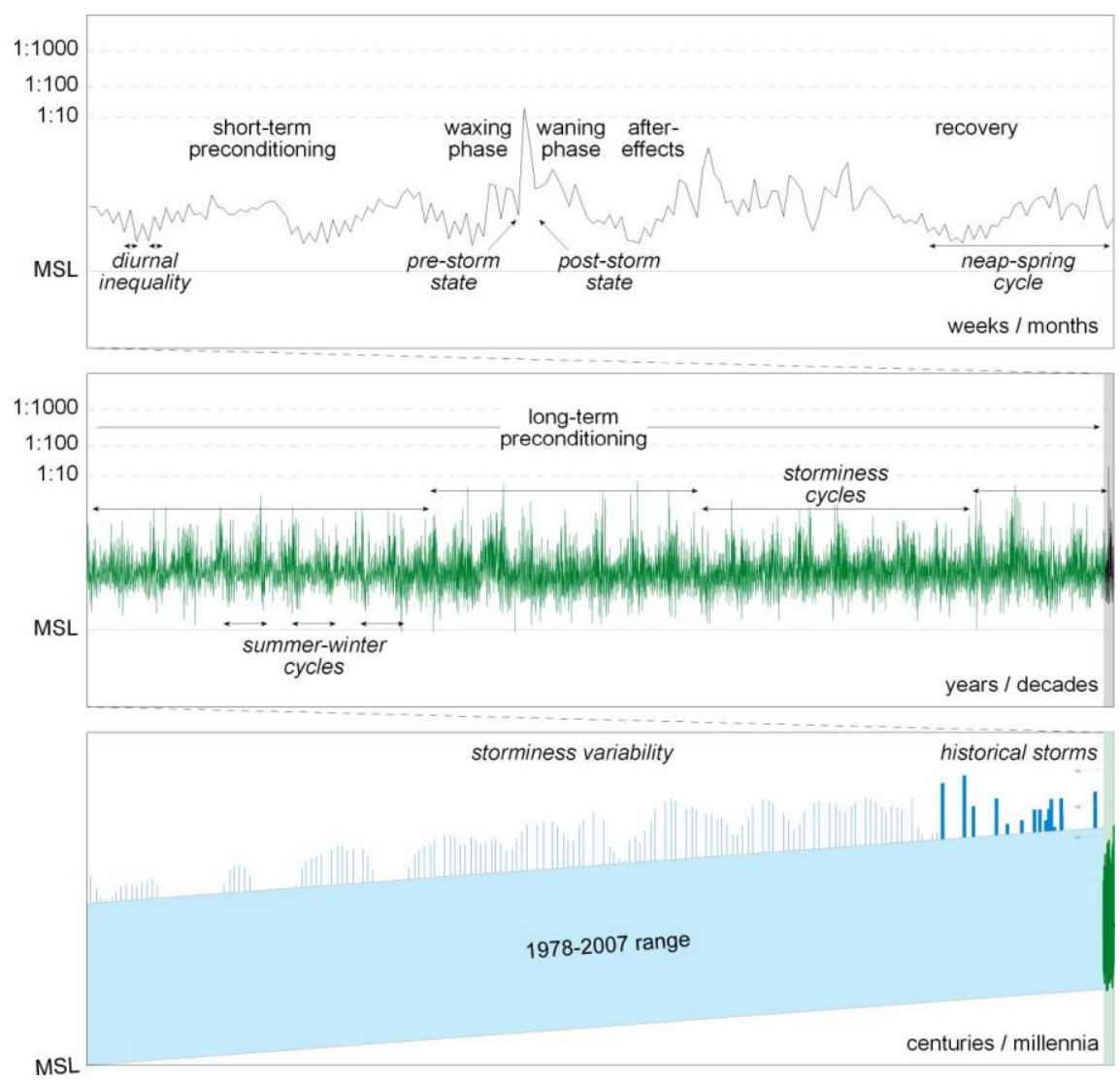

Figure 20 - Elements to be considered in the analysis of barrier response to storms. The upper diagram shows the waxing and waning of a 1:20-year storm within the context of preconditioning, after-effects and recovery, using flood levels measured at the entrance of Rotterdam harbour (Netherlands) between October 1 and December 31, 2007 (data from www.waterbase.nl). Levels for 1:10-, 1:100- and 1:1000-year recurrence intervals are shown for reference. Storm coincidence with diurnal higher high waters and spring high tides adds to its impact. The middle panel visualises types of long-term preconditioning, using water level measured at the same station between January 1, 1978 and December 31, 2007. The black curve on the right corresponds to the curve of the top diagram. Aside from consistent seasonal patterns with autumn and winter storms, periods of higher and lower water-level extremes can be identified, with lower extremes providing better opportunities for barrier recovery and maturation. The lower diagram conceptualises climate-related variability in storm frequency and intensity, showing the effects of relative sea-level rise and NOA variability. The green curve on the right corresponds to the curve of the middle panel; the bold isolated peaks on the righthand side represent historical water-levels exceeding the 1978-2007 range; and the thin peaks to their left form a hypothesised long-term storminess pattern.

Following the preconditioning phase, the storm itself consists of a waxing and a waning phase (e.g., Wang et al., 2006) that jointly determine the post-storm state. The waxing phase is dominated by erosion, particularly in the subaerial environment. Increasingly powerful waves and rising water levels impact a coastal zone that is out of equilibrium with these extreme conditions. Although dominated by erosion as well, the waning phase may include substantial depositional elements. Significant sedimentation may take place nearshore and on the shoreface (Hayes, 1967). Decreasing and increasingly dissipated wave energy and falling water levels also provide an opportunity for early subaerial recovery. These depositional aspects (e.g., Keen and Stone, 2000) have received relatively little attention, but opposite behaviour of different coastal indicators create an increasing awareness of the importance to monitor shoreline positions as well as profile-volume increases and decreases.

For weeks after a storm has ended, after-effects influence sedimentary processes on beaches and barriers. At Heemskerk in the Netherlands, a 2007 storm surge left steeply scarped dunes vulnerable to post-storm slumping. On broad barriers, long-term ponding of flood waters from overwash in interior lows prevents aeolian reworking of sediment and may stimulate the growth of salt-tolerant maintainer species that inhibit subsequent morphological recovery. On narrower barriers, storm passes may remain active for extended periods of time. Offshore, storm-generated mega-cusps and mega-rip channels in embayed settings may persist for several months and continue to act as conduits for offshore sediment transport under non-storm conditions, considerably postponing beach recovery until the rip-neck and feeder channels are infilled (Loureiro et al., 2012).

Recovery from any storm is a key component of preconditioning for the next storm. It has a strong effect on pre-storm beach and barrier state as can be illustrated using the four categories of post-storm barrier response defined by Morton et al. (1994): continued erosion, partial recovery, complete recovery and over-recovery (Figure 21). Increased resilience by over-recovery 
lessens the danger of critical thresholds, whereas decreased resilience by continued erosion or partial recovery makes exceedance of thresholds during subsequent storms more likely. When systems become so depleted that they disintegrate, there may never be enough time between later storms for recovery, even with large-scale human intervention. A typical recovery phase is marked by large-scale transport of sediment during fair-weather conditions. Upon termination of a storm, onshore reworking of temporary nearshore and shoreface storm deposits results in onshore bar migration, followed by bar welding and foreshore accretion, which sets into motion backshore aggradation, dune formation and colonization of barren sediment by vegetation (Morton et al., 1994). Recovery depends in part on the local availability of sediment (Forbes et al., 2004). It is greatest where pre-storm profile volumes were largest (Houser and Hamilton, 2009) and hampered where moisture and lag deposits create temporary or permanent supplylimited conditions (e.g., Davidson-Arnott et al., 2005). If sediment is not sufficiently available, surviving beach and barrier parts may become subject to accelerated erosion (Houser et al., 2009).
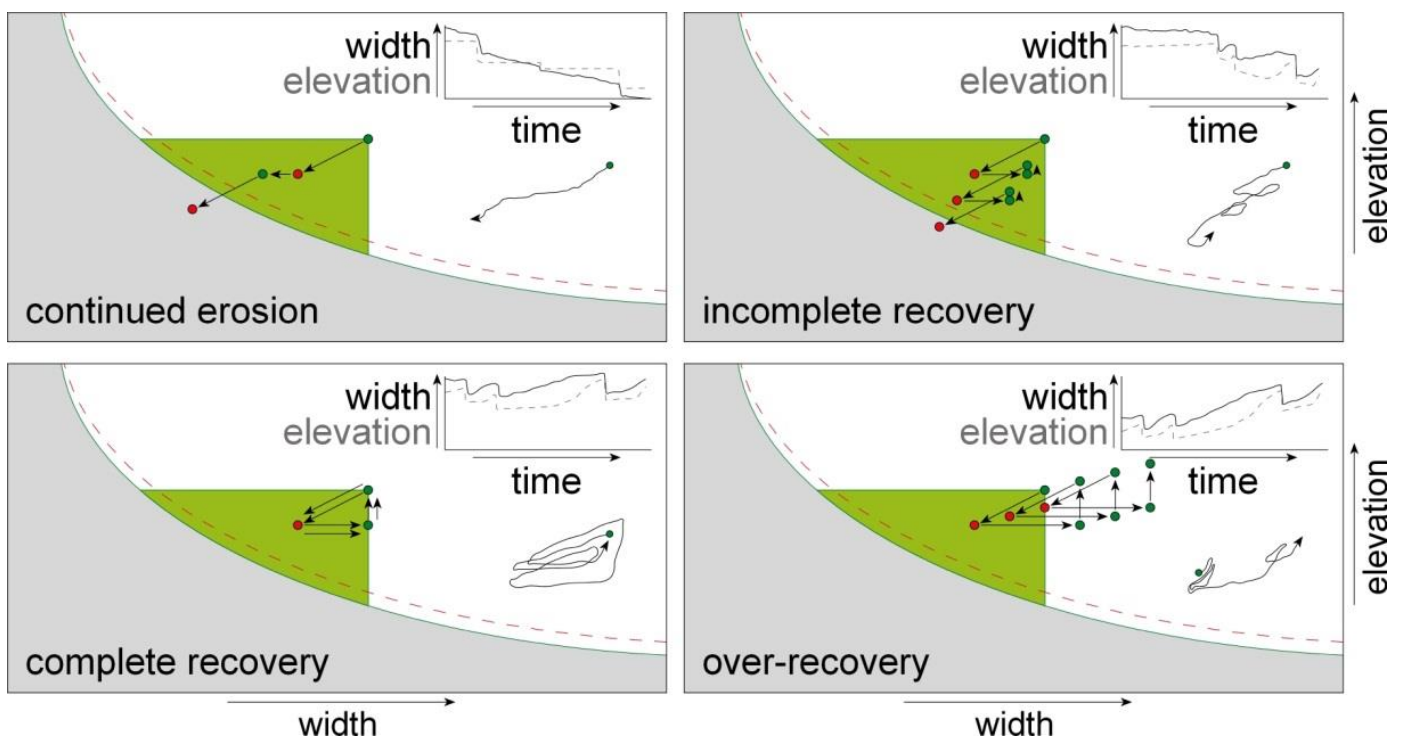

Figure 21 - Influence of recovery on barrier response to storm cycles. Continued erosion (upper left) and incomplete recovery (upper right), either related to limited sediment availability or a result of closely spaced storms, increase the likelihood of threshold exceedance. Complete recovery (lower left) and over-recovery (lower right) maintain or strengthen barrier integrity. Next to the simplified representations in the green resilience triangles, the curvy lines give more realistic resilience trajectories. The graph in the right-hand corner of each panel gives the corresponding barrier width and crest elevation time series.

Generally, beaches recover more quickly than dunes, and beach recovery begins immediately after a storm. It may be complete within days to months (Cazes-Duvat, 2005; Wang et al., 2006; Bramato et al., 2012), but can last years to more than a decade following some extreme storm (e.g., Thom and Hall, 1991; Morton et al., 1994; Zhang et al., 2002). Dune recovery may take decades, especially where storm passes and overwash breaches need to be healed (Forbes et al., 2004). There are exceptions to this rule, with Stone et al. (2004) observing dune recovery outpacing foreshore at Santa Rosa Island in Florida following Hurricane Opal. Dune recovery may be accelerated when offshore winds rework washovers (Leatherman, 1976). It is also strongly aided by vegetation where specialised pioneering species colonise, and thus stabilise, storm-damaged areas (Pries et al., 2008). The higher the density and the more extensive the plant coverage, the more efficient sediment can be trapped (e.g., Snyder and Boss, 2002), although entrapment capabilities and effects on recovery are strongly dependent on plant species (Wolner et al., 2013). The time needed for recovery may be longer than the intervals between consecutive storms and in that case severe cumulative effects on beaches and barriers are likely. Houser and Hamilton (2009), for example, contrasted the response of a Florida barrier to Hurricane Opal in 1995, following seven decades of fair-weather-dominated development, with its subsequent behaviour. The clustered Hurricanes Ivan, Dennis and Katrina in 2004 and 2005 destroyed incipient dunes that were still vulnerable following Opal. The extent of recovery, therefore, depends in part on storm frequency (Christiansen and Davidson-Arnott, 2004). When given enough time, beaches and dunes are re-established at positions consistent with their long-term migration trend (Zhang et al., 2002), as long as no critical erosion threshold has been exceeded.

To assess barrier health and predict long-term resilience trajectories, multi-decadal barrier behaviour must be analysed in light of critical thresholds and non-linearity. Such analyses are in short supply, complicated by observational records that usually characterise storm impact by means of simple before-and-after comparisons for the most spectacular events. Short monitoring periods and low temporal resolutions do not match with the time frame of barrier change, and bias toward developed North American, western European and Australian barriers with great socio-economical value carries the risk of overlooking mobilityrelated resilience in more natural barriers. Although the many excellent studies of barrier response to storms have provided us with some strong and convincing controls on generic processes, site-specific factors have mostly been ignored. Regional sediment availability and longshore sediment transport, which play key roles in recovery and preconditioning, are least understood. 
A fundamental task of future research is the quantification of long-term barrier response to climate change. Observed sea-level rise and potentially increasing storm intensity reduce recovery times and increase the likelihood of thresholds being exceeded (Figure 22). Expected changes in storm frequency will also not be without effect. At the crossroads between climate-related research and barrier studies, keys to success are in-situ measurements during extreme storms, needed to enhance process-response understanding (waxing and waning phases, thresholds and feedbacks), long and high-resolution time series that include storm and fair-weather conditions, and a new generation of behavioural and numerical models that link short- and long-term barrier behaviour. In recent years, models fore- and hindcasting drivers of the difference storm-response regimes and quantifying actual barrier response to individual events have been improved and coupled. Upgrading and integrating models of barrier response to sea-level change is a next challenge. Once tackled successfully, accurate forecasting of $21^{\text {st }}$-century barrier change will be within reach.
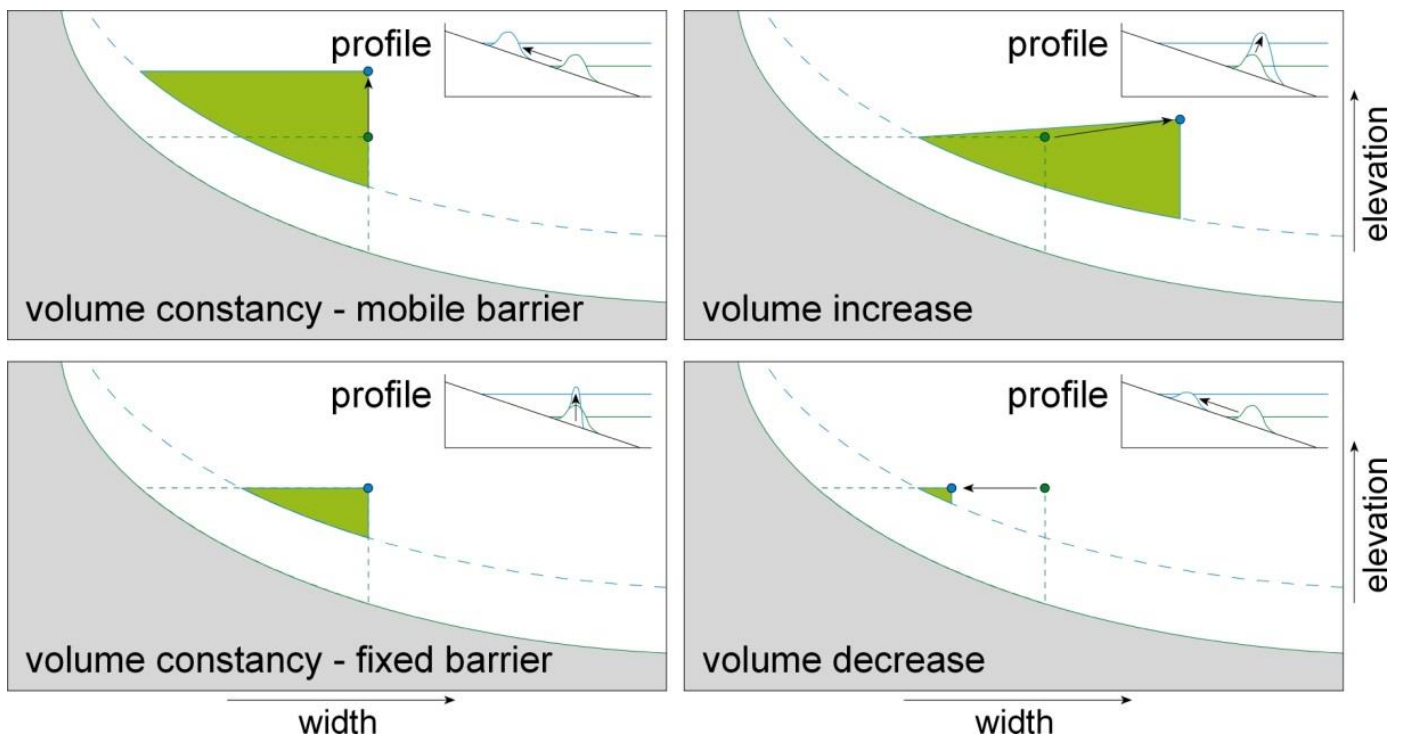

Figure 21-Changing barrier resilience in response to relative sea-level rise or increasing maximum water levels related to growing storm intensity. The threshold shifts created by these processes trigger various modes of barrier response that may or may not be sufficient for long-term survival. For the scenario of sea-level rise, a natural barrier marked by volume constancy will tend to migrate landward (upper left). Under the same volume constancy, a barrier that is fixed in position, either because of coastal setting or as a result of human measures (e.g., seawall), will ultimately drown and disintegrate (lower left). Volume increase (e.g., by beach nourishment) will allow a barrier to remain in position or even expand seaward (upper right), whereas a volume decrease is bound to result in barrier destruction (lower right).

\section{References}

Aagaard, T., Kroon, A., Andersen, S., Sorensen, R.M., Quartel, S. and Vinther, N., 2005. Intertidal beach change during storm conditions; Egmond, The Netherlands. Marine Geology 218, 65-80.

Aagaard, T., Orford, J. and Murray, A., 2007. Environmental controls on coastal dune formation: Skallingen Spit, Denmark. Geomorphology 83, 29-47.

Aagaard, T., Hughes, M., Baldock, T., Greenwood, B., Kroon, A. and Power, H., 2012. Sediment transport processes and morphodynamics on a reflective beach under storm and non-storm conditions. Marine Geology 326, 154-165.

Aernouts, D., Héquette, A., 2006. L'évolution du rivage et des petits fonds en Baie de Wissant pendant le XXè siècle, Pas-deCalais, France. Géomorphologie: Relief, Processus et Environnement 1, 49-64.

Alegria-Arzaburu, A. and Masselink, G., 2010. Storm response and beach rotation on a gravel beach, Slapton Sands, U.K Marine Geology 278, 77-99, doi:10.1016/j.margeo.2010.09.004.

Alexander, L.V., Tett, S.F.B. and Jonsson, T., 2005. Recent observed changes in severe storms over the United Kingdom and Iceland. Geophysical Research Letters 32, doi: 10.1029/2005g1022371.

Almeida, L.P., Vousdoukas, M.V., Ferreira, O., Rodrigues, B.A. and Matias, A., 2012. Thresholds for storm impacts on an exposed sandy coastal area in southern Portugal. Geomorphology 143, 3-12.

Anthony, E.J., 2013. Storms, shoreface morphodynamics, sand supply, and the accretion and erosion of coastal dune barriers in the southern North Sea (2012). Geomorphology (in press).

Archetti, R. and Romagnoli, C., 2011. Analysis of the effects of different storm events on shoreline dynamics of an artificially embayed beach. Earth Surface Processes and Landforms 36, 1449-1463.

Armaroli, C. and Ciavola, P., 2010. Dynamics of a nearshore bar system in the northern Adriatic: a video-based morphological classification. Geomorphology 126, 201-216, doi: 10.1016/j.geomorph.2010.11.004.

Armaroli, C., Ciavola, P., Perini, L., Calabrese, L., Lorito, S., Valentini, A. and Masina, M., 2012. Critical storm thresholds for significant morphological changes and damage along the Emilia-Romagna coastline, Italy. Geomorphology 143, 34-51.

Battjes, J.A., 1974. Surf similarity. Proceedings 14th Conference on Coastal Engineering, ASCE, 466-480. 
Betts, N.L., Orford, J.D., White, D. and Graham, C.J., 2004. Storminess and surges in the South-Western Approaches of the eastern North Atlantic: the synoptic climatology of recent extreme coastal storms. Marine Geology 210, $227-246$.

Bradbury, A.P., 1998. Predicting breaching of shingle barriers beaches - recent advances to aid beach management. Proceedings 35th Annual MAFF Conference of River and Coastal Engineers.

Bradbury, A.P. and Powell, K.A., 1993. Short-term profile response of shingle spits to storm wave action. Proceedings of the Coastal Engineering Conference, 3, pp. 2694-2707.

Bradbury, A.P., Cope, S.N. and Prouty, D.B., 2005. Predicting the response of shingle barrier beaches under extreme wave and water level conditions in Southern England. Coastal Dynamics '05, ASCE, paper on CD-ROM.

Bramato, S., Ortega-Sanchez, M., Mans, C. and Losada, M.A., 2012. Natural recovery of a mixed sand and gravel beach after a sequence of a short duration storm and moderate sea states. Journal of Coastal Research 28, 89-101.

Brodie, K.L. and McNinch, J.E., 2009. Measuring bathymetry, runup, and beach volume change during storms: New methodology quantifies substantial changes in cross-shore sediment flux. Poster, AGU Fall Meeting 2009 (abstract: adsabs.harvard.edu//abs/2009AGUFMNH11A1111B).

Brodie, K.L., Slocum, R.K. and McNinch, J.E., 2012. New insights into the physical drivers of wave runup from a continuously operating terrestrial laser scanner. OCEANS 2012 MTS/IEEE: Harnessing the Power of the Ocean, art. no. 6404955

Buynevich, I.V. and Donnelly, J.P., 2006. Geological signatures of barrier breaching and overwash, southern Massachusetts, USA. Journal of Coastal Research, SI39 (Proceedings of the 8th International Coastal Symposium), 112-116. Itajaí, SC, Brazil, ISSN 0749-0208.

Cañizares, R. and Irish, J.L., 2009. Simulation of storm-induced barrier island morphodynamics and flooding. Coastal Engineering 55, 1089-1101.

Carter, R.W.G. and Orford, J.D., 1981). Overwash processes along a gravel beach in south-east Ireland ( Carnsore Point). Earth Surface Processes and Landforms 6, 413-426.

Carter, R.W.G., Hesp, P.A., Nordstrom, K.F., 1990. Erosional landforms in coastal dunes. In: Nordstrom, K.F., Psuty, N., Carter, R.W.G. (Eds.), Coastal Dunes. Form and Process. Wiley, London, pp. 217-246.

Castelle, B., Turner, I.L., Ruessink, B.G. and Tomlinson, R.B., 2007. Impact of storms on beach erosion: Broadbeach (Gold Coast, Australia). Journal of Coastal Research SI50, 534-539.

Cazes-Duvat, V., 2005. The morphologic impacts of cyclone Kalunde on the beaches of Rodrigues island (Western Indian Ocean). Zeitschrift Fur Geomorphologie 49, 293-308.

Christiansen, M.B. and Davidson-Arnott, R., 2004. Rates of landward sand transport over the foredune at Skallingen, Denmark and the role of dune ramps. Geografisk Tidsskrift $104,31-43$.

Church, J. A. and White, N.J., 2011. Sea-level rise from the late 19th to the early 21st Century. Surveys in Geophysics 32, 585602, doi:10.1007/s10712-011-9119-1.

Claudino-Sales, V., Wang, P. and Horwitz, M.H., 2008. Factors controlling the survival of coastal dunes during multiple hurricane impacts in 2004 and 2005: Santa Rosa barrier island, Florida. Geomorphology 95, 295-315.

Claudino-Sales, V., Wang, P. and Horwitz, M.H., 2010. Effect of hurricane ivan on coastal dunes of Santa Rosa Barrier Island, Florida: Characterised on the basis of pre- and poststorm LIDAR surveys. Journal of Coastal Research 26, $470-484$.

Coco, G., Senechal, N., Rejas, A., Bryan, K.R., Capo, S., Parisot, J.-P., Brown, J. and MacMahan, J., submitted. Beach response to a sequence of storms. Geomorphology.

Conley, D.C. and Beach, R.A., 2003. Cross-shore sediment transport partitioning in the nearshore during a storm event. Journal of Geophysical Research 108, 3065, doi: 10.1029/2001jc001230.

Cooper, J.A.G., Jackson, D.W.T., Navas, F., McKenna, J. and Malvarez, G., 2004. Identifying storm impacts on an embayed, high-energy coastline: examples from western Ireland. Marine Geology 210, 261-280.

Coutts-Smith, A., 2004. The significance of mega-rips along an embayed coast. PhD thesis, School of Geosciences, University of Sydney, $221 \mathrm{pp}$.

Cowell, P.J., Stive, M.J.F., Niedoroda, A.W., De Vriend, H.J., Swift, D.J.P., Kaminsky, G.M. and Capobianco, M., 2003. The Coastal-Tract (Part 1): A Conceptual Approach to Aggregated Modelling of Low-Order Coastal Change. Journal of Coastal Research 19, 812-827.

Davidson-Arnott, R.G.D., MacQuarrie, K. and Aagaard, T., 2005. The effect of wind gusts, moisture content and fetch length on sand transport on a beach. Geomorphology 68, 115-129.

Del Rio, L., Plomaritis, T.A., Benavente, J., Valladares, M. and Ribera, P., 2012. Establishing storm thresholds for the Spanish Gulf of Cadiz coast. Geomorphology 143, 13-23.

Dingler, J.R. and Reiss, T.E., 1995. Beach erosion on Trinity Island, Louisiana, caused by Hurricane Andrew. Journal of Coastal Research SI 21, 254-264.

Dolan, R. and Godfrey, P.J., 1973. Effects of Hurricane Ginger on the barrier islands of North Carolina. Geological Society of America Bulletin 84, 1329-1334.

Dolan, R. and Hayden, B., 1981. Storms and shoreline configuration. Journal of Sedimentary Petrology 51, 737-744.

Donnelly, C., Kraus, N. and Larson, M., 2006. State of knowledge on measurement and modelling of coastal overwash. Journal of Coastal Research 22, 965-991.

Donnelly, C., 2007. Morphologic Change by Overwash - Establishing and Evaluating Predictors. Journal of Coastal Research, SI 50 (Proceedings of the 9th International Coastal Symposium), 520 - 526. Gold Coast, Australia, ISSN 0749.0208.

Ehrenfeld, J.G., 1990. Dynamics and processes of barrier island vegetation. Reviews in Aquatic Sciences 2, 437-480.

Emanuel, K. A., 2007. Environmental factors affecting tropical cyclone power dissipation. Journal of Climate 20, 5497-5509.

Esteves, L.S., Brown, J.M., Williams, J.J. and Lymbery, G., 2012. Quantifying thresholds for significant dune erosion along the Sefton Coast, Northwest England. Geomorphology 143-144, 52-61. 
Fichaut, B. and Suanez, S., 2011. Quarrying, transport and deposition of cliff-top storm deposits during extreme events: Banneg Island, Brittany. Marine Geology 283, 36-55.

Fiore, M.M.E., D'Onofrio, E.E., Pousa, J.L., Schnack, E.J. and Bertola, G.R., 2009. Storm surges and coastal impacts at Mar del Plata, Argentina. Continental Shelf Research 29, 1643-1649.

Fisher, J.S., Leatherman, S.P. and Perry, F.C., 1974. Overwash processes on Assateague Island. Proceedings 14th Coastal Engineering Conference, ASCE, 1194-1211.

Flather, R.A., 1987. Estimates of extreme conditions of tide and surge using a numerical model of the northwest European continental-shelf. Estuarine Coastal and Shelf Science 24, 69-93.

Forbes, D.L., Parkes, G.S., Manson, G.K. and Ketch, L.A., 2004. Storms and shoreline retreat in the southern Gulf of St. Lawrence. Marine Geology 210, 169-204.

Fritz, H.M., Blount, C., Sokoloski, R., Singleton, J., Fuggle, A., McAdoo, B.G., Moore, A., Grass, C. and Tate, B., 2007. Hurricane Katrina storm surge distribution and field observations on the Mississippi Barrier Islands. Estuarine Coastal and Shelf Science 74, 12-20.

Galal, E.M. and Takewaka, S., 2011. The influence of alongshore and cross-shore wave energy flux on large- and small-scale coastal erosion patterns. Earth Surface Processes and Landforms 36, 953-966.

Gallagher, E.L., Elgar, S. and Guza, R.T., 1998. Observations of sand bar evolution on a natural beach. Journal of Geophysical Research 103, 3203-3215.

Garcez Faria, A.F., Thornton, E.B., Stanton, T.P., Soares, C.V. and Lippmann, T.C., 1998. Vertical profiles of longshore currents and related bed shear stress and bottom roughness. Journal of Geophysical Research 103, 3217-3232, doi: 10.1029/97JC02265

Garcez Faria, A.F., Thornton, E.B., Lippmann, T.C. and Stanton, T.P., 2000. Undertow over a barred beach. Journal of Geophysical Research 105, 16999-17010, doi: 10.1029/2000JC90008.

Gervais, M., Balouin, Y. and Belon, R., 2012. Morphological response and coastal dynamics associated with major storm events along the Gulf of Lions Coastline, France. Geomorphology 143, 69-80.

Godfrey, P.J. and Godfrey, M.M., 1973. Comparison of ecological and geomorphic interactions between altered and unaltered barrier island systems in North Carolina. In: Coates, D.R. (Ed.), Coastal Geomorphology. State Univ. New York, New York, pp. 239-258.

Godfrey, P.J. and Godfrey, M.M., 1976. Barrier island ecology of Cape Lookout National Seashore and vicinity, North Carolina. NPS Scientific Monograph Series, No. 9. National Park Service, Cape Hatteras Natl. Seashore, NC.

Godfrey, P.J., Leatherman, S.P. and Zaremba, R., 1979. A geobotanical approach to classification of barrier beach systems. In: Leatherman, S.P. (Ed.), Barrier islands: From the Gulf of St. Lawrence to the Gulf of Mexico. Acad. Press, New York, NY, pp. 99-126.

Goff, J.A., Allison, M.A. and Gulick, S.P.S., 2010. Offshore transport of sediment during cyclonic storms: Hurricane Ike (2008), Texas Gulf Coast, USA. Geology 38, 351-354.

Grzegorzewski, A.S., Cialone, M.A. and Wamsley, T.V., 2011. Interaction of barrier islands and storms: Implications for flood risk reduction in Louisiana and Mississippi. In: Roberts, T.M., Rosati, J.D. and Wang, P. (eds.), Proceedings, Symposium to Honor Dr. Nicholas C. Kraus, Journal of Coastal Research, SI59, 156-164.

Gutierrez, B.T., S.J. Williams, and E.R. Thieler, 2009: Ocean coasts. In: Coastal Sensitivity to Sea-Level Rise: A Focus on the Mid-Atlantic Region. A report by the U.S. Climate Change Science Program and the Subcommittee on Global Change Research. [J.G. Titus (coordinating lead author), K.E. Anderson, D.R. Cahoon, D.B. Gesch, S.K. Gill, B.T. Gutierrez, E.R. Thieler, and S.J. Williams (lead authors)]. U.S. Environmental Protection Agency, Washington DC, pp. 43-56.

Guza, R.T. and Inman, D.L., 1975. Edge waves and beach cusps. Journal of Geophysical Research 80, 2997-3012.

Guza, R.T. and Thornton, E.B., 1982. Swash oscillations on a natural beach. Journal of Geophysical Research 87, $483-491$.

Haerens, P., Bolle, A., Trouw, K. and Houthuys, R., 2012. Definition of storm thresholds for significant morphological change of the sandy beaches along the Belgian coastline. Geomorphology 143, 104-117.

Haigh, I., Nicholls, R. and Wells, N., 2011. Rising sea levels in the English Channel 1900 to 2100. Maritime Engineering 164: 8192.

Hall, A.M., 2011. Storm wave currents, boulder movement and shore platform development: A case study from East Lothian, Scotland. Marine Geology 283, 98-105.

Hall, A.M., Hansom, J.D., Williams, D.M. and Jarvis, J., 2006. Distribution, geomorphology and lithofacies of cliff-top storm deposits: Examples from the high-energy coasts of Scotland and Ireland. Marine Geology 232, 131-155.

Hanson, J.L., Friebel, H.C. and Hathaway, K.K., 2009. Coastal wave energy dissipation: Observations and STWAVE-FP performance. $11^{\text {th }}$ International Workshop on Wave Hindcasting and Forecasting \& 2nd Coastal Hazards Symposium; Halifax, Nova Scotia, Canada.

Harley, M.D., Turner, I.L., Short, A.D. and Ranasinghe, R., 2011. A reevaluation of coastal embayment rotation: The dominance of cross-shore versus alongshore sediment transport processes, Collaroy-Narrabeen Beach, southeast Australia. Journal of Geophysical Research 116, doi: 10.1029/2011JF001989.

Hayes, M.O., 1967, Hurricanes as geological agents; case studies of Hurricane Carla, 1961 and Cindy, 1963: Austin, University of Texas Bureau of Economic Geology Report 61, 56 p.

Hequette, A. and Hill, P.R., 1995. Response of the seabed to storm-generated combined flows on a sandy Arctic shoreface, Canadian Beaufort Sea. Journal of Sedimentary Research A: Sedimentary Petrology \& Processes, 461-471.

Héquette, A. and Ruz, M.-H., 1991. Spit and barrier island migration in the southeastern Canadian Beaufort Sea. Journal of Coastal Research 7, 677-698.

Hill, H.W., Kelley, J.T., Belknap, D.F. and Dickson, S.M., 2004. The effects of storms and storm-generated currents on sand beaches in Southern Maine, USA. Marine Geology 210, 149-168. 
Hite, M.P., 1924. Some observations on storm effects on ocean inlets. American Journal of Science 7, 319-326.

Hoefel, F. and Elgar, S., 2003. Wave-induced sediment transport and sandbar migration. Science 299, 1885-1887, doi: $10.1126 /$ science. 1081448.

Holman, R.A. and Stanley, J., 2007. The history and technical capabilities of Argus. Coastal Engineering 54, 477-491.

Hosier, P.E., Cleary,W.J., 1977. Cyclic geomorphic patterns of washover on a barrier island in southeastern North Carolina. Environmental Geology 2, 23-31.

Houser, C., 2009. Synchronization of transport and supply in beach-dune interaction. Progress in Physical Geography, 33 733746.

Houser, C., 2013. Alongshore variation in the morphology of coastal dunes: Implications for storm response. Geomorphology (in press).

Houser, C., Greenwood, B., 2005. Profile response of a lacustrine multiple barred nearshore to a sequence of storm events. Geomorphology 69, 118-137.

Houser, C. and Hamilton, S., 2009. Sensitivity of post-hurricane beach and dune recovery to event frequency. Earth Surface Processes and Landforms 34, 613-628.

Houser, C., Hapke, C. and Hamilton, S., 2008. Controls on coastal dune morphology, shoreline erosion and barrier island response to extreme storms. Geomorphology 100, 223-240.

Houser, C.; Hobbs, C. and Saari, B., 2008. Posthurricane airflow and sediment transport over a recovering dune. Journal of Coastal Research, 24(4), 944-953. West Palm Beach (Florida), ISSN 0749-0208.

Idier, D., Dumas, F. and Muller, H., 2012. Tide-surge interaction in the English Channel. Natural Hazards and Earth System Science 12, 3709-3718.

Judge, E.K., Overton, M.F. and Fisher, J.S., 2003. Vulnerability indicators for coastal dunes. Journal of Waterway, Port, Coastal, and Ocean Engineering 129, 270-278.

Kamphuis, J., 1991. Alongshore sediment transport rate. Journal of Waterway, Port, Coastal, and Ocean Engineering 117, 624640.

Keen, T.R. and Slingerland, R.L., 1993, Four storm-event beds and the tropical cyclones that produced them: A numerical hindcast: Journal of Sedimentary Petrology 63, 218-232.

Keen, T.R. and Stone, G.W., 2000. Anomalous response of beaches to hurricane waves in a low-energy environment, northeast Gulf of Mexico. Journal of Coastal Research 16, 1100-1110.

Keim, B.D., Muller, R.A. and Stone, G.W., 2004. Spatial and temporal variability of coastal storms in the North Atlantic Basin. Marine Geology 210, 7-15.

Knutson, T.R., McBride, J.L., Chan, J., Emanuel, K., Holland, G., Landsea, C.,Held, I., Kossin, J.P., Srivastava, A.K. and Sugi, M., 2010. Tropical cyclones and climate change. Nature Geoscience 3, 157-163.

Komar, P.D., 1998. Beach Processes and Sedimentation. Prentice Hall, New Jersey.

Komar, P.D. and Inman, D.L., 1970. Longshore sand transport on beaches. Journal of Geophysical Research 75, 5914-5927.

Kroonenberg, S.B., Badyukova, E.N., Storms, J.E.A., Ignatov, E.I. and Kasimov, N.S., 2000. A full sea-level cycle in 65 years: Barrier dynamics along Caspian shores. Sedimentary Geology 134, 257-274.

Łabuz, T.A., 2005. Present-day dune environment dynamics on the coast of the Świna Gate Sandbar (Polish West coast). Estuarine, Coastal and Shelf Science 62, 507-520.

Lambert, S.J. and Fyfe, J.C., 2006. Changes in winter cyclone frequencies and strengths simulated in enhanced greenhouse warming experiments: results from the models participating in the IPCC diagnostic exercise. Climate Dynamics 26, $713-728$.

Lapinskis, J. 2005: Long-term fluctuations in the volume of beach and foredune deposits along the coast of Latvia. Baltica 18, 3843.

Leatherman, S.P., 1976. Quantification of Overwash Processes., Charlottesville, Virginia: Department of Environmental Sciences, University of Virginia, Ph.D. dissertation, 245 pp.

Leatherman, S.P., 1979. Barrier dune systems: a reassessment. Sedimentary Geology 24, 1-16.

Leatherman, S.P., 1985. Geomorphic and Stratigraphic Analysis of Fire Island, New York. Marine Geology 63, $173-195$.

Lemm, A.J. and Hegge, B.J. and Masselink, G., 1999. Offshore wave climate, Perth (Western Australia): 1994-1996. Marine and Freshwater Research 50, 95-102.

Lentz, E.E. and Hapke, C., 2011. Geologic framework influences on the geomorphology of an anthropogenically modified barrier island: assessment of dune/beach changes at Fire Island, New York. Geomorphology 126, 82-96.

Lentz, E.E., Hapke, C.J., Stockdon, H.F. and Hehre, R.E., 2013. Improving understanding of near-term barrier island evolution through multi-decadal assessment of morphologic change. Marine Geology 337, 125-139.

Lindhorst, S., Fürstenau, J., Christian Hass, H. and Betzler, C., 2010. Anatomy and sedimentary model of a hooked spit (Sylt, southern North Sea). Sedimentology 57, 935-955.

Lippmann, T.C. and Holman, R.A., 1990. The spatial and temporal variability of sand bar morphology. Journal of Geophysical Research 95, 11575-11590.

List, J.H., Jaffe B.E. and Sallenger A.H., Jr., 1991. Large-scale coastal evolution of Louisiana's barrier islands. In: Proceedings Coastal Sediments 1991, ASCE, 1532-1546.

List, J.H., Farris, A.S. and Sullivan, C., 2006. Reversing storm hotspots on sandy beaches: spatial and temporal characteristics. Marine Geology 226, 261-279.

Loureiro, C., Ferreira, O. and Cooper, J.A.G., 2012. Extreme erosion on high-energy embayed beaches: Influence of megarips and storm grouping. Geomorphology 139, 155-171. 
Lowe, J.A., Howard, T., Pardaens, A., Tinker, J., Holt, J., Wakelin, S., Milne, G., Leake, J., Wolf, J., Horsburgh, K., Reeder, T., Jenkins, G., Ridley, J., Dye, S. and Bradley, S., 2009. UK Climate Projections science report: Marine and coastal projections. Met Office Hadley Centre, Exeter, UK.

Marino-Tapia, I., Russell, P.E., O'Hare, T., Davidson, M.A. and Huntley, D.A., 2007a. Cross-shore sediment transport on natural beaches and its relation to sandbar migration patterns. Part 1: Field observations and derivation of a transport parameterization. Journal of Geophysical Research 112, C03001, doi:10.1029/2005JC002893.

Marino-Tapia, I., O'Hare, T., Russell, P.E., Davidson, M.A. and Huntley, D.A., 2007b. Cross-shore sediment transport on natural beaches and its relation to sand bar migration patterns: Part 2: Application of the field transport parameterization. Journal of Geophysical Research 112, C03002, doi:10.1029/2005JC002894.

Masselink, G. and Black, K.P., 1995. Magnitude and cross-shore distribution of bed return flow on natural beaches. Coastal Engineering 25, 165-190.

Masselink, G. and Pattiaratchi, C.B., 2001. Seasonal changes in beach morphology along the sheltered coastline of Perth, Western Australia. Marine Geology 172, 242-263.

Masselink, G. and Puleo, J.A., 2006. Swash-zone morphodynamics. Continental Shelf Research 26, 661-680.

Matias, A., Williams, J.J., Masseling, G. and Ferreira, Ó, 2012. Overwash threshold for gravel barriers. Coastal Engineering 63, 48-61.

McBride, R.A. and Robinson, M.M., 2003. Geomorphic evolution and geology of Old Currituck Inlet and its flood tidal delta, Virginia/North Carolina, USA (Part I). Proceedings Coastal Sediments '03, ASCE.

McBride, R.A., Taylor, M.J. and Byrnes, M.R., 2007. Coastal morphodynamics and chenier-plain evolution in southwestern Louisiana, USA: A geomorphic model. Geomorphology 88, 367-422.

McCall, R., Masselink, G., Roelvink, D., Russell, P.E., Davidson, M. and Poate, T., 2012. Modelling overwash on gravel barriers. Proceedings 33rd International Conference on Coastal Engineering, ASCE, paper 700.

Meehl, G.A. and many others, 2007. Global climate projections. In: Climate Change 2007: The Physical Science Basis. Contribution of Working Group I to the Fourth Assessment Report of the Intergovernmental Panel on Climate Change, pp. 433-497, Cambridge University Press, Cambridge, UK.

Morton, R.A., 2002. Factors controlling storm impacts on coastal barriers and beaches - A preliminary basis for near real-time forecasting. Journal of Coastal Research 18, 486-501.

Morton, R.A., Paine, J.G. and Gibeaut, J.C., 1994. Stages and durations of poststorm beach recovery, southeastern Texas coast. Journal of Coastal Research 10, 884-908.

Nicholls, R.J. and Cazenave, A., 2010. Sea level rise and its impact on coastal zones. Science 328, 1517-1520.

Nicholls, R.J. and others, 2011. Sea-level rise and its possible impacts given a 'beyond 4oC world' in the twenty-first century. Philosophical Transactions Royal Society Series A 369, 161-181.

Nishi, R. and Kraus, N.C., 1996. Mechanism and calculation of sand dune erosion by storms. Proceedings of 25th Conference on Coastal Engineering, ASCE, 3034-3047.

O'Reilly,W.C., Guza, R.T., 1993. A comparison of two spectral wave models in the Southern California Bight. Coastal Engineering 19, 263-282.

Orford, J.D. and Anthony, E.J., 2011. Extreme events and the morphodynamics of gravel-dominated coastal barriers: Strengthening uncertain ground. Marine Geology 290, 41-45.

Orford, J.D. and Carter, R.W.G., 1982. The structure and origins of recent sandy gravel overtopping and overwashing features at Carnsore Point, southeast Ireland. Journal of Sedimentary Petrology 52, 265- 278.

Orford, J.D., Forbes, D.L. and Jennings, S.C., 2002. Organisational controls, typologies and time scales of paraglacial graveldominated coastal systems. Geomorphology 48, 51-85.

Orford, J., Jennings, S. and Pethick, J., 2003. Extreme storm effect on gravel-dominated barriers. Proc. Coastal Sediments '03. ASCE, CD-ROM.

Osborn, T. J., 2004. Simulating the winter North Atlantic Oscillation: the roles of internal variability and greenhouse gas forcing. Climate Dynamics, 22, 605-623, doi:10.1007/s00382-004-0405-1.

Palmsten, M.L. and Holman, R.A., 2011. Infiltration and instability in dune erosion. Journal of Geophysical Research, 116, C10030, doi: 10.1029/2011JC007083.

Penland, S. and Suter, J.R., 1984. Process response models for Gulf coast barrier island breaching. Transactions Gulf Coast Association of Geological Societies 34, 397-400.

Penland, S.; Suter, J.R.; Sallenger, A.H.; Williams, S.J.; McBride, R.A.; Westphal, K.E.; Reimer, P.D. and Jaffe, B.E., 1989. Morphodynamic signature of the 1985 hurricane impacts on the northern Gulf of Mexico. Coastal Zone 1989, 5, 4220-4234.

Plant, N.G., Freilich, M.H. and Holman, 2001. Role of feedback in surf zone sand bar response. Journal of Geophysical Research, 106, 973-989.

Plant, N.G., Holland, K.T. and Holman, R.A., 2006. A dynamical attractor governs beach response to storms. Geophysical Research Letters 33, L17607, doi: 10.1029/2006g1027105.

Price, T.D. and Ruessink, B.G., 2011. State dynamics of a double sandbar system. Continental Shelf Research 31, 659-674.

Pries, A.J.; Miller, D.L., and Branch, L.C., 2008. Identification of structural and spatial features that influence storm-related dune erosion along a barrier-island ecosystem in the Gulf of Mexico. Journal of Coastal Research 24 168-175.

Priestas, A.M. and Fagherazzi, S., 2010. Morphological barrier island changes and recovery of dunes after Hurricane Dennis, St. George Island, Florida. Geomorphology 114, 614-626.

Pye, K. and Blott, S.J., 2008. Decadal-scale variation in dune erosion and accretion rates: An investigation of the significance of changing storm tide frequency and magnitude on the Sefton coast, UK. Geomorphology 102, 652-666. 
Qi, H.S., Cai, F., Lei, G., Cao, H.M. and Shi, F.Y., 2010. The response of three main beach types to tropical storms in South China. Marine Geology 275, 244-254.

Ranasinghe, R. G. Symonds, K. Black and R. Holman. 2004. Morphodynamics of intermediate beaches: A video imaging and numerical modelling study. Coastal Engineering 51, 629-655.

Rangel-Buitrago, N. and Anfuso, G., 2011. Coastal storm characterization and morphological impacts on sandy coasts. Earth Surface Processes and Landforms 36, 1997-2010.

Regnauld, H. and Louboutin, R., 2002. Variability of sediment transport in beach and coastal dune environments, Brittany, France. Sedimentary Gerology 150, 17-29.

Regnauld, H., Pirazzoli, P.A., Morvan, G. and Ruz, M., 2004. Impacts of storms and evolution of the coastline in western France. Marine Geology 210, 325-337.

Rosati, J.D., Dean, R.G. and Stone, G.W., 2010. A cross-shore model of barrier island migration over a compressible substrate. Marine Geology 271, 1-16.

Roy, P.S., Cowell, P.J., Ferland, M.A. and Thom, B.G., 1994. Wave-dominated coasts. In: R.W.G. Carter and C.D. Woodroffe (editors), Coastal Evolution, Cambridge University Press, Cambridge, 87-120.

Ruessink, B.G., Kleinhans, M.G. and van den Beukel, P.G.L., 1998. Observations of swash under highly dissipative conditions. Journal of Geophysical Research 103, 3111-3118.

Ruessink, B.G., Wijnberg, K.M., Holman, R.A., Kuriyama, Y. and van Enckevort, I.M.J., 2003. Intersite comparison of interannual bar behaviour. Journal of Geophysical Research 108, doi: 10.1029/2002JC001505.

Ruessink, B.G., 2010. Observations of turbulence in the surf zone. Journal of Physical Oceanography 40, 2696-2712, doi: 10.1175/2010jpo4466.1.

Ruggiero, P., Buijsman, M., Kaminsky, G.M. and Gelfenbaum, G., 2010. Modelling the effects of wave climate and sediment supply variability on large-scale shoreline change. Marine Geology 273, 127-140.

Russell, P.E. and Huntley, D.A., 1999. A cross-shore transport shape function for high energy beaches. Journal of Coastal Research 15, 198-205.

Sallenger, A.H., 2000. Storm impact scale for barrier islands. Journal of Coastal Research 16, 890-895.

Sallenger, A.H., Holman, R.A. and Birkemeier, W.A., 1985. Storm- induced response of a nearshore-bar system. Marine Geology 64, 237

Sallenger, A.H., Stockdon, H.F., Fauver, L., Hansen, M., Thompson, D., Wright, C.W. and Lillycrop, J., 2006. Hurricanes 2004: An overview of their characteristics and coastal change. Estuaries and Coasts 29, 880-888.

Sallenger, A., Wright, W., Lillycrop, J., Howd, P., Stockdon, H., Guy, K. and Morgan, K., 2007. Extreme changes to barrier islands along the central Gulf of Mexico coast during Hurricane Katrina. In Farris, G.S., Smith, G.J., Crane, M.P., Demas, C.R., Robbins, L.L. and Lavoie, D.L., eds., 2007, Science and the storms - the USGS response to the hurricanes of 2005: U.S. Geological Survey Circular 1306, p. 113-118. [http://pubs.usgs.gov/circ/1306/].

Savage, R.P., 1985. Hurricane Alicia storm surges and shore processes. Proceedings of the Coastal Engineering Conference, 1, 257-270.

Saye, S.E., Van der Wal, D., Pye, K. and Blott, S.J., 2005. Beach-dune morphological relationships and erosion/accretion: An investigation at five sites in England and Wales using LIDAR data. Geomorphology 72, 128-155.

Sedrati, M., Anthony, E.J., 2007. Storm-generated morphological change and longshore sand transport in the intertidal zone of a multi-barred macrotidal beach. Marine Geology 244, 209-229.

Senechal, N., Abadie, S., Gallagher, E., MacMahan, J., Masselink, G., Michallet, H., Reniers, A., Ruessink, G., Russell, P., Sous, D., Turner, I., Ardhuin, F., Bonneton, P., Bujan, S., Capo, S., Certain, R., Pedreros, R. and Garlan, T., 2011 a. The ECORSTruc Vert'08 nearshore field experiment: presentation of a three-dimensional morphologic system in a macro-tidal environment during consecutive extreme storm conditions. Ocean Dynamics 61, 2073-2098.

Senechal, N., Coco, G., Bryan, K.R. and Holman, R.A., 2011b. Wave runup during extreme storm conditions. Journal of Geophysical Research 116, C07032, doi: 10.1029/2010JC006819.

Shaw, J., Taylor, R.B. and Forbes, D.L., 1993. Impact of the Holocene Transgression on the Atlantic Coastline of Nova Scotia. Géographie physique et Quaternaire 47, 221-238.

Short, A.D., 1978. Wave power and beach-stages: A global model. Proceedings 16th International Conference on Coastal Engineering, ASCE, 1145- 1162.

Short, A.D., 1985. Rip-current type, spacing and persistence, Narrabeen Beach, Australia. Marine Geology 65, 47-71.

Snyder, R.A. and Boss, C.L., 2002. Recovery and stability of Barrier Island plant communities. Journal of Coastal Research 18, 530-536.

Splinter, K.D., Holman, R.A. and Plant, N.G., 2011. A behaviour-oriented dynamic model for sandbar migration and 2DH evolution. Journal of Geophysical Research, 116, C01020, doi: 10.1029.2010/JC006382.

Stallins, J.A., 2005. Stability domains in Barrier Island dune systems. Ecological Complexity 2,. 410-430.

Stive, M.J.F. and De Vriend, H.J., 1995. Modelling shoreface profile evolution. Marine Geology 126, 235-248.

Stockdon, H.F., Holman, R.A., Howd, P.A. and Sallenger Jr., A.H., 2006. Empirical parameterization of setup, swash, and runup. Coastal Engineering 53, 573-588.

Stockdon, H.F., Sallenger, A.H., Holman, R.A. and Howd, P.A., 2007. A simple model for the spatially-variable coastal response to hurricanes. Marine Geology 238, 1-20.

Stockdon, H.F., Doran, K.S. and Sallenger, A.H., 2009. Extraction of Lidar-based dune-crest elevations for use in examining the vulnerability of beaches to inundation during hurricanes. Journal of Coastal Research 25, 59-65.

Stone, G.W., Liu, B., Pepper, D.A. and Wang, P., 2004. The importance of extratropical and tropical cyclones on the short-term evolution of barrier islands along the northern Gulf of Mexico, USA. Marine Geology 210, 63-78. 
Suter, J.R.; Nummedal, D.; Maynard, A.K., and Kemp, P., 1982. A process-response model for hurricane washovers. Proceedings 18th Coastal Engineering Conference, ASCE, 1459-1789.

Thom, B.G and Hall, W. 1991: Behavior of beach profiles during accretion and erosion dominated periods. Earth Surface Processes and Landforms 16, 113-27.

Thomas, T., Phillips, M.R., Williams, A.T. and Jenkins, R.E., 2011. Medium timescale beach rotation; gale climate and offshore island influences, Geomorphology 135, 97-107, doi:10.1016/j.geomorph.2011.08.002.

Thornton, E.B., MacMahan J. and Sallenger Jr., A.H., 2007. Rip currents, mega-cusps, and eroding dunes. Marine Geology 240, 151-167.

Thornton, E.B., Humiston, R.T. and Birkemeier, W., 1996. Bar/trough generation on a natural beach. Journal of Geophysical Research 101, 12097-12110

Timmons, E.A., Rodriguez, A.B., Mattheus, C.R. and DeWitt, R., 2010. Transition of a regressive to a transgressive barrier island due to back-barrier erosion, increased storminess, and low sediment supply: Bogue Banks, North Carolina, USA. Marine Geology 278, 100-114.

Trenberth, K.E. and Shea, D.J., 2006. Atlantic hurricanes and natural variability in 2005. Geophysical Research Letters 33, doi: $10.1029 / 2006 \mathrm{gl} 1026894$.

Trifonova, E.V., Valchev, N.N., Andreeva, N.K. and Eftimova, P.T., 2012. Critical storm thresholds for morphological changes in the western Black Sea coastal zone. Geomorphology 143, 81-94.

Tsimplis, M.N., Woolf, D.K., Osborn, T., Wakelin, S., Woodworth, P., Wolf, J., Flather, R., Blackman, D., Shaw, A.G.P., Pert, F., Challenor, P. and Yan, Z., 2005. Towards a vulnerability assessment of the UK and northern European coasts: the role of regional climate variability. Philosophical Transactions: Mathematical, Physical \& Engineering Sciences, doi:10.1098/rsta.2005.1571.

Turki, I., Medina, R., Gonzalez, M. and Coco, G., 2013. Natural variability of shoreline position: Observations at three pocket beaches. Marine Geology 338, 76-89, 10.1016/j.margeo.2012.10.007.

Van de Graaff, J., 1986. Probabilistic design of dunes, an example from The Netherlands. Coastal Engineering 9, 479-500.

van de Graaff, J., 1994. Coastal dune erosion under extreme conditions. In: Finkl, C.W. (Ed.), Coastal Hazards- Perception, Susceptibility and Mitigation. Journal of Coastal Research Special Issue 12, 253-262.

Van Heteren, S., in press. Chapter 9: Barrier systems. In: Masselink, G. and Gehrels, W.R. (editors), Coastal Environments and Global Change. Wiley-Blackwell.

Vecchi, G.A., and Knutson, T.R., 2011. Estimating annual numbers of Atlantic hurricanes missing from the HURDAT database (1878-1965) using ship track density. Journal of Climate 24, 1736-1746.

Vermeer, M. and Rahmstorf, S., 2009. Global sea level linked to global temperature. Proceedings National Academy of Science USA 106, 21527-21532.

Virmani, J.I. and Weisberg, R.H., 2006. The 2005 hurricane season: An echo of the past or a harbinger of the future? Geophysical Research Letters 33, doi: 10.1029/2005g1025517.

Walsh, K.J.E., McInnes, K.L. and McBride, J.L., 2012. Climate change impacts on tropical cyclones and extreme sea levels in the South Pacific - A regional assessment. Global and Planetary Change 80-81, 149-164.

Wang, P. and Horwitz, M.H., 2007. Erosional and depositional characteristics of regional overwash deposits caused by multiple hurricanes. Sedimentolog, 54, 545-546.

Wang, P., Kirby, J.H., Haber, J.D., Horwitz, M.H., Knorr, P.O. and Krock, J.R., 2006. Morphological and sedimentological impacts of Hurricane Ivan and immediate poststorm beach recovery along the northwestern Florida barrier-island coasts. Journal of Coastal Research 22, 1382-1402.

Webster, P.J., Holland, G.J., Curry, J.A and Chang, H.-R., 2005. Changes in tropical cyclone number, duration and intensity in a warming environment. Science 309, 1844-1846.

Wolf, J. and Flather, R.A., 2005. Modelling waves and surges during the 1953 storm. Philosophical Transactions A Mathemetics Physics Engineering Science 363, 1359-1375.

Wolner, C.W.V., Moore, L.J., Young, D.R., Brantley, S.T., Bissett, S.N. and McBride, R.A., 2013. Ecomorphodynamic feedbacks and barrier island response to disturbance: Insights from the Virginia Barrier Islands, Mid-Atlantic Bight, USA. Geomorphology (in press).

Woodroffe, C.D. and Murray-Wallace, C.V., 2012. Sea-level rise and coastal change: the past as a guide to the future. Quaternary Science Reviews 54, 4-11.

Woolf, D.K., Challenor, P.G., and Cotton, P.D., 2002). The variability and predictability of North Atlantic wave climate. Journal of Geophysical Research, 107(C10), 3145, doi: 10.1029/2001JC001124.

Wright, L.D. and Short, A.D., 1984. Morphodynamic variability of surf zones and beaches: A synthesis. Marine Geology 56, 93118.

Wright, L.D., Chappell, J., Thom, B.G., Bradshaw, M.P. and Cowell, P. 1979: Morphodynamics of reflective and dissipative beach and inshore systems: southeastern Australia. Marine Geology 70, 251-85.

Wu, L.G., Wang, B. and Geng, S.Q., 2005. Growing typhoon influence on east Asia. Geophysical Research Letters 32, doi: $10.1029 / 2005 \mathrm{gl} 1022937$.

Xhardé, R., Long, B.F. and Forbes, D.L., 2011. Short-term beach and shoreface evolution on a cuspate foreland observed with airborne topographic and bathymetric LIDAR. In: Pe'eri, S. and Long, B. (eds.), Applied LIDAR Techniques, Journal of Coastal Research, SI 62, 50-61.

Zhang, K., Douglas, B. and Leatherman, S., 2002. Do storms cause long-term beach erosion along the U.S. East Barrier Coast? Journal of Geology 110, 493-502. 